\title{
ГЕОГРАФИЯ
}

Научная статья

УДК 911.52 (913(4/9):631.44) + (911.2:581.524.4)

$10.18101 / 2542-0623-2020-3 / 4-84-108$

\section{ЛАНДШАФТНАЯ СТРУКТУРА ПРИОЛЬХОНЬЯ}

\section{С. Б. Кузьмин, С. И. Шаманова}

\section{(C) Кузьмин Сергей Борисович}

доктор географических наук, ведущий научный сотрудник, Институт географии им. В. Б. Сочавы СО РАН Россия, 664033, г. Иркутск, ул. Уланбаторская, 1 kuzmin@irigs.irk.ru

\section{(C) Шаманова Светлана Игоревна}

кандидат биологических наук, научный сотрудник, Сибирский институт физиологии и биохимии растений СО РАН Россия, 664033, г. Иркутск, ул. Лермонтова, 132 shamanova2009@yandex.ru

Аннотация. Проведены исследования ландшафтной структуры полигона-трансекта в Приольхонье, Западное Прибайкалье. В результате установлено, что характер геоморфологических процессов и соответствующего им комплекса рыхлых отложений тесно связан с различиями в солярной, циркуляционной и гравитационной экспозиции склонов. Экспозиция склонов и морфология поверхности оказывают влияние на структуру почвенного покрова и особенности почв. Анализ размещения почв в ландшафтах выявил независимые склоновые экспозиционные серии почв: северные и южные. Растительные сообщества юго-восточных и северо-западных склонов контрастно отличаются по видовому составу. Смена геоморфологических условий в пределах склонов определенной экспозиции обусловливает ряд последовательно сменяющих друг друга растительных сообществ по мере изменения литоморфности и степени увлажнения субстрата. В границах полигона-трансекта выделено 19 фаций, пространственное распределение которых отражает основные закономерности дифференциации ландшафтов Приольхонья, обусловленные микро- и мезоклиматическими различиями экспозиционного положения, удаленности от Байкала, морфологии поверхности; особенностями проявления ведущих геоморфологических процессов и различиями в реакции горных пород на их воздействие; литологической неоднородностью подстилающей поверхности.

Ключевые слова: пространственная структура ландшафтов; геоморфологические условия, почвы; структура растительности; Западное Прибайкалье.

\section{Для цитирования}

Кузьмин С. Б., Шаманова С. И. Ландшафтная структура Приольхонья // Природа Внутренней Азии. Nature of Inner Asia. 2020. № 3/4(16). С. 84-108.

DOI: $10.18101 / 2542-0623-2020-3 / 4-84-108$ 


\section{Введение}

Приольхоньем традиционно называют территорию в средней части западного берега оз. Байкал напротив о. Ольхон с интразональным набором компонентов природы. Это своеобразный «остров» степных и лесостепных ландшафтов среди типичных южнотаежных лесов Восточной Сибири. В данной работе под Приольхоньем понимается территория, простирающаяся с юго-востока на северо-запад от береговой линии оз. Байкал до водораздела Приморского хребта на отрезке между поселками Бугульдейка и Зама, включая Кучелго-Таловскую депрессию и Приольхонское.

Общие черты ландшафтной структуры Приольхонья определяются ее положением в Байкало-Джугджурской физико-географической области. Специфика высотно-поясной ландшафтной дифференциации, включающей практически полный набор ландшафтов всего горного окружения оз. Байкал, обусловлена проявлением барьерно-теневого, аридно-котловинного и подгорного климатических эффектов, осложненных влиянием водной массы озера. В результате этого формируется сочетание контрастных по природным условиям ландшафтов: североазиатских, восточно-сибирских гольцовых (подгольцовых), таежных светлохвойных, южно-сибирских таежных темнохвойных, степных. Главная особенность современной ландшафтной структуры территории Приольхонья - это взаимопроникновение и тесное взаимодействие горно-таежных и горно-степных ландшафтов, формирующих экотон (контакт) горной тайги и степи, представленный сочетанием горно-таежных светлохвойных, подгорных лиственничных остепненных и горно-степных ландшафтов [Ландшафты... 1977; Снытко и др., 2001].

Географическое взаимопроникновение и взаимодействие ландшафтов, относящихся в целом к различным типам природной среды, составляет специфическую черту всего бассейна оз. Байкал. Проявление региональных и субрегиональных экотонов наиболее ярко выражено в ландшафтной организации внутригорных понижений. Соседство таежных светлохвойных, подтаежных и степных ландшафтов типично для горных котловин Прибайкалья, Забайкалья и юга Центральной Сибири. Но особенность Приольхонья состоит в том, что здесь на ограниченной площади выражены закономерности ландшафтной организации, свойственные как котловинам байкальского типа, так и всему бассейну оз. Байкал [Михеев, 2001]. Это и определяет актуальность изучения ландшафтной структуры региона.

\section{Процедура исследований}

Основной задачей работы является установление пространственных закономерностей в распределении внутриландшафтных подразделений топологического ранга: ландшафт - местность - урочище - фация [Раменский, 1938; Солнцев, 2001]. Детальные исследования ландшафтной структуры проводились на модельном полигоне-трансекте ландшафтного макропрофиля, наиболее полно отражающем характер контакта горной тайги и степи (Рис. 1). Трансект ориентирован по направлению «северо-запад - юго-восток» от предгорий Приморского хребта до байкальского побережья. Такое направление, поперек простирания основных морфоструктурных и морфоскульптурных элементов рельефа, выбрано не случайно. Оно позволяет трассировать наиболее контрастные структурные подразделения ландшафтов - отдельные местности (главные морфоструктуры рельефа) и урочища (главные морфоскульптуры рельефа): северные и южные склоны, 
вершины, днища суходолов и т.п., которые включают наибольшее количество элементарных ландшафтных выделов - фаций. В основу работы положены как новые материалы, так и обобщения многолетних исследований авторов [Кузьмин, Шаманова, 2012; Кузьмин и др., 2012, 2014, 2016].

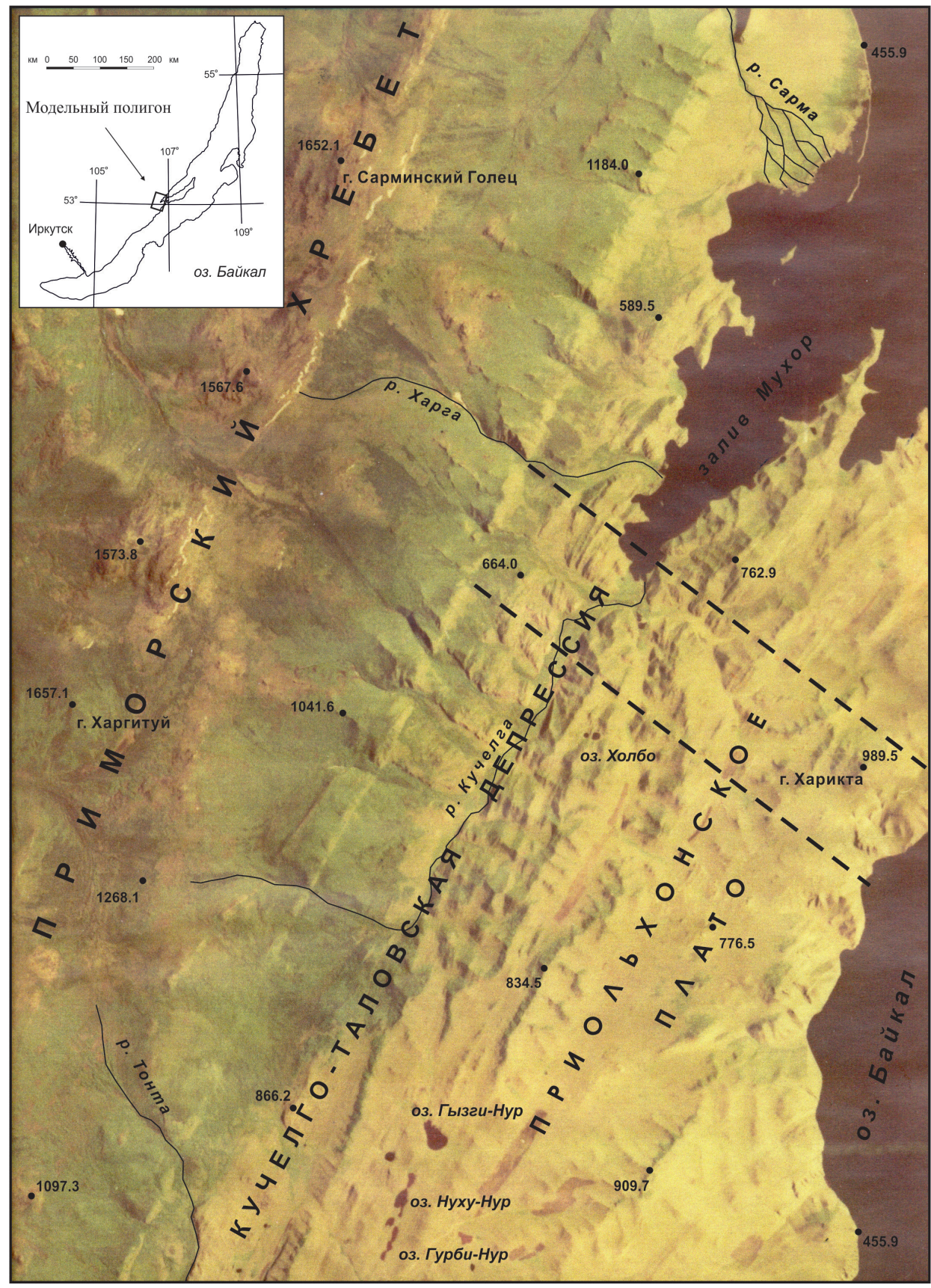

Puc. 1. Район исследований. Штриховыми линиями показан модельный полигонтрансект. Спектрозональный космический снимок LANDSAT для простоты восприятия, монохромный вариант 
Ландшафтная организация компонентов природы полигона-трансекта отражена в пространственной упорядоченности его территориальных подразделений - ландшафтной структуре. Ее изучение основано на анализе ландшафтов топологической размерности, элементарных гетерогенных ареалов - местностей и урочищ - и элементарных гомогенных ареалов - фаций. Исходной единицей проведенного анализа выбран элементарный разнокачественный ареал - урочище. Низшей категорией анализа выбран элементарный гомогенный ареал - фация, под которым понимается внутриландашфтное структурное подразделение, на всем своем протяжении сохраняющее единство литологического и петрографического состава горных пород, микроклиматических и геоморфологических параметров, характеризующееся одной почвенной разностью и биоценозом. Гомогенные ареалы, формирующиеся в одинаковых местоположениях, тождественны друг другу по своим морфологическим (физиономическим) характеристикам. Эти участки единой фации могут быть разобщены в пространстве.

Критериями выделения ландшафтных местностей на полигоне-трансекте являются особенности морфоструктуры рельефа, для урочищ - особенности морфоскульптуры рельефа и характеристики почв, для фаций - особенности растительности на элементарных местопроизрастаниях.

\section{Рельеф и геоморфологические процессы}

Основным рельефообразующим морфоструктурным элементом района является Приморский хребет, крутой до $45-50^{\circ}$ юго-восточный склон которого оформляет зона Приморского разлома. Заложен разлом в нижнем протерозое, имеет длительную историю тектонического развития, связанную со становлением Байкальской рифтовой зоны (БРЗ), активен в настоящее время. В рельефе Приморский разлом выражен в виде грандиозного эскарпа-уступа с перепадом высот до 1000 м в районе дельты р. Сарма (рис. 2).

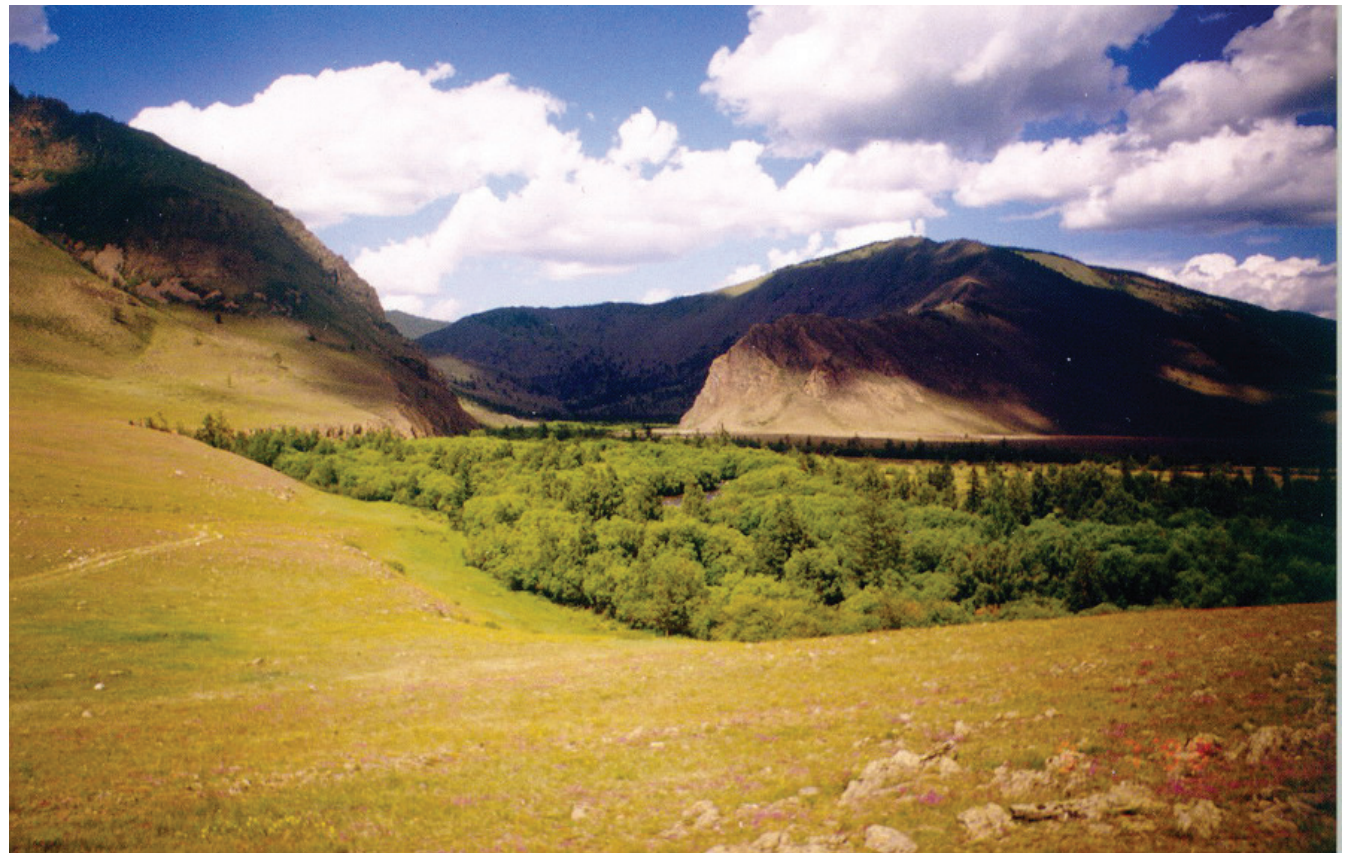

Рuc. 2. Эскарп Приморского разлома в районе устья р. Сармы (фото С. Б. Кузьмина) 
По зоне Приморского разлома заложена Кучелго-Таловская депрессия, частично затопленная водами Байкала в районе залива Мухор (рис. 1), с абсолютными отметками высот от 440 до 600 м. Она выработана по мелкому грабену-сателлиту БР3, на контакте опущенного и поднятого крыла Приморского разлома. В основании уступа Приморского разлома на его поверхности обычны проявления современной и четвертичной тектоники, выраженные в виде систем «уступ-микрограбен» и секущие поверхность предгорного делювиального шлейфа - характерная ситуация для БРЗ.

Массив Приморского хребта отличается среднегорным, местами глубоко расчлененным рельефом с абсолютными отметками до 1500-1700 м. Водоразделы полого-покатые, со слабоконтрастным холмисто-увалистым рельефом. Вершины хребта представлены плоскими гольцами, на которых повсеместно развиваются криогенные процессы, образующие уникальные формы рельефа. Северо-западный склон, в отличие от юго-восточного, пологий, плавно переходит к морфоструктурам Сибирской платформы.

В нескольких местах Приморский хребет насквозь прорезается реками, впадающими в оз. Байкал - Кучелга, Харга, Сарма, Анга. Долины их антецедентные, древнее, чем сам хребет, имели до начала неотектонических движений в БРЗ сток в сторону Сибирской платформы. Мелкие реки и ручьи, стекающие с Приморского хребта, часто не достигают Кучелго-Таловской депрессии, теряя свои воды в высокотрещиноватых зонах Приморского разлома. Продольные профили этих рек, заложенные вкрест простирания разлома, характеризуются многочисленными резкими перепадами, которые в рельефе представлены уступами с камнепадами высотой до 20-30 м.

Низкогорный слабоконтрастный холмисто-увалистый и лощинно-западинный рельеф Приольхонского плато с абсолютными высотами до 800-900 м осложнен линейно вытянутыми структурными грядами, гребнями и холмами, суффозионными воронками, карстовыми полостями и останцами причудливой формы. Многочисленные замысловато извилистые долины, сухие или слабообводненные, с пологими днищами и бортами, расчленяют рельеф на ансамбль мелких котловин и возвышенностей. Край плато, обращенный к оз. Байкал, представляет собой достаточно обрывистый извилистый уступ с перепадом высот до уровня воды 400-500 м, заложенный по зоне Обручевского разлома. Уступ испещрен мелкими заливами и мысами. Северо-западный край плато имеет менее контрастный переход к Кучелго-Таловской депрессии с перепадами высот 100-150 м, выработанный по зоне древнего Чернорудско-Баракчинского разлома (рис. 3).

Прямолинейностью, подчиненной общей геолого-тектонической структуре БРЗ, обладают многие элементы рельефа Приольхонья: узкие вытянутые гребни, гряды, холмы, предгорные прогибы мелких хребтов. Оси гребней и гряд простираются в целом на 40-50 . Их длина составляет в среднем 100-300 м при ширине 10-50 м и высоте 10-40 м. На ограниченном пространстве плато представлены системы параллельных невысоких гребней, выраженных чередованием слоев мраморов и гнейсов, различных по устойчивости к денудационным процессам. В большинстве случаев юго-восточная экспозиция гряд значительно круче северо-западной. 


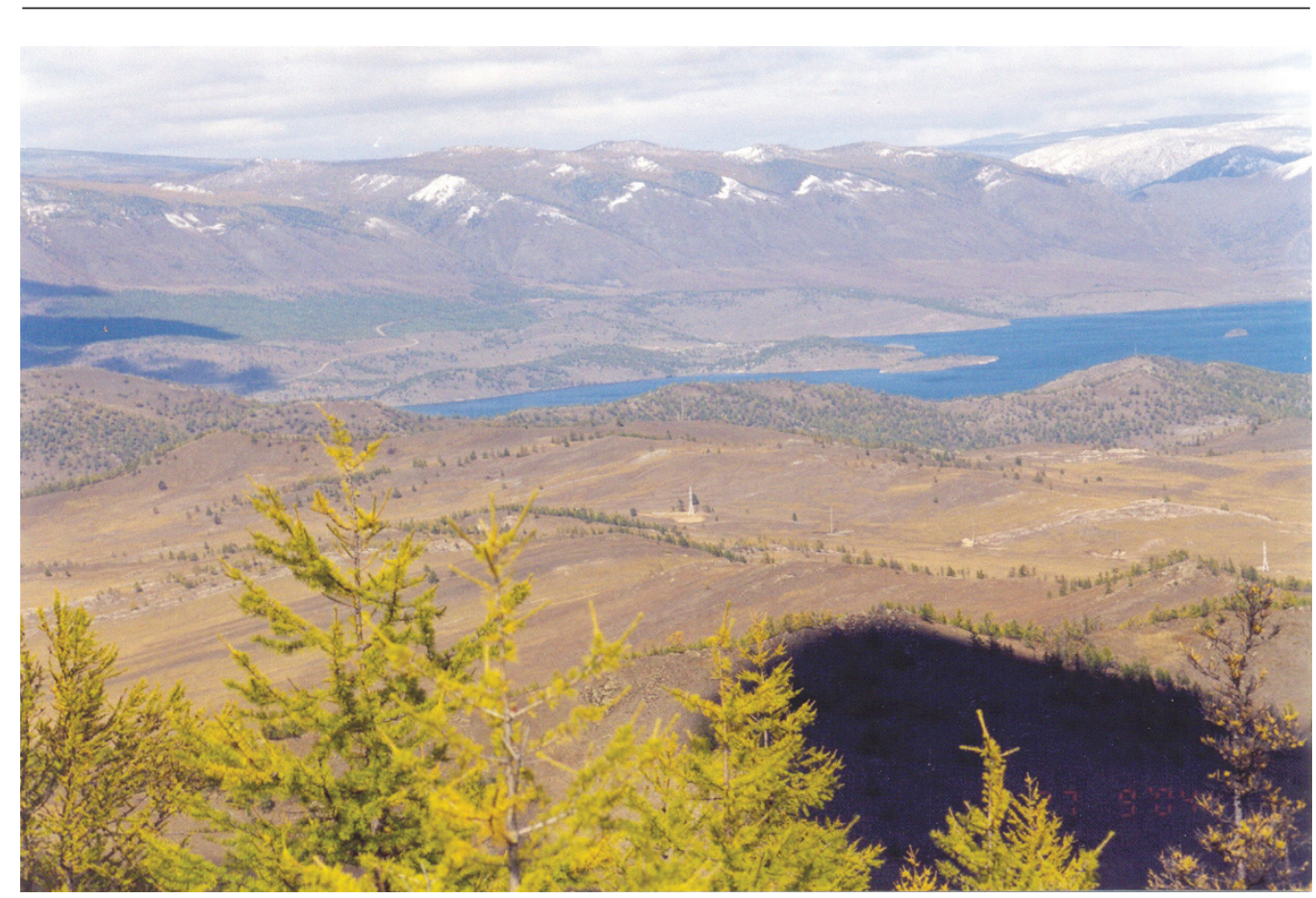

Puc. 3. Общий вид (с юга на север) рельефа и ландшафтов в районе полигонатрансекта. На дальнем плане - Приморский хребет с эскарпом Приморского разлома, на переднем - Приольхонское плато с мелкосопочным рельефом, в середине между ними - Кучелго-Таловская депрессия (фото С. Б. Кузьмина)

Инсоляционная и циркуляционная экспозиция склонов, абсолютная высота местности определяют отклонения микроклимата склонов на полигоне от мезоклиматических условий всего Приольхонья в сторону иссушения или, наоборот, увлажнения. Основные климатические различия в пределах полигона формируются вследствие экспозиционной ориентации склонов. Солярный и циркуляционный эффект взаимно усиливают друг друга. Юго-западным и южным склонам присущ относительно наиболее сухой микроклимат, северо-восточным и северным - наиболее влажный.

Различия в солярной, циркуляционной и гравитационной экспозиции склонов как раз и обусловливают характер геоморфологических процессов и соответствующего им комплекса рыхлых отложений. Ландшафтам разных высотных уровней и морфоскульптурных форм рельефа также соответствует свой набор геоморфологических процессов (табл. 1).

В границах полигона-трансекта на всех локальных склонах развиты денудационные и эоловые процессы, на северных склонах проявляется также дефлюкция. Протяженность и характер поверхности, циркуляционная и солярная экспозиции склонов обусловливают разные сценарии развития их структурных элементов. Так, денудация преобладает в верхних частях всех склонов, а также хорошо выражена в средней части южных крутых склонов Приольхонского плато и примыкающих к нему склонов Кучелго-Таловской депрессии. Собственно денудационные склоны внутри полигона-трансекта не имеют широко распространения, но доминируют на его периферии - склоны, оформляющие Приморский и 
Чернорудско-Баракчинский разломы. Активный транзит вещества более развит в средней части северных и нижней части южных склонов, аккумуляция - в нижней части северных склонов и на выположенных подножьях южных склонов.

Узкие водоразделы, приводораздельные склоны и уступы (последние превалируют на южных склонах) сложены грубым элювием разнообразных, обычно массивно-кристаллических пород с многочисленными скальными обнажениями. На приводораздельных относительно выровненных участках северных склонов, а также пологоволнистых водоразделах формируются элювиально-делювиальные щебнистые и супесчаные отложения, редко прерываемые выходами коренных горных пород, за исключением участков с карбонатными породами, особенно мраморами. В средней части северных склонов и нижней части южных склонов развиты маломощные (менее 1 м) делювиальные хрящеватые супесчаные, реже суглинистые и песчаные отложения. Днища широких суходольных распадков, котловины выполнены рыхлыми отложениями различного генезиса (делювиальные, флювиально-делювиальные, пролювиальные, аллювиальные, озерные) и мощности.

Таблица 1

Геоморфологические процессы на полигоне-трансекте

\begin{tabular}{|c|c|c|c|}
\hline Группа процессов & $\begin{array}{l}\text { Ведущие } \\
\text { процессы }\end{array}$ & Формы рельефа & $\begin{array}{c}\text { Высотный } \\
\text { пояс, м }\end{array}$ \\
\hline Мерзлотные & $\begin{array}{l}\text { термоэрозия, } \\
\text { термокарст, } \\
\text { пучение грунтов, } \\
\text { десерпция } \\
\end{array}$ & $\begin{array}{l}\text { поймы рек, водораздельные } \\
\text { гольцовые эквиплены, } \\
\text { подгольцовые морозобойные } \\
\text { террасы и ниши вымораживания }\end{array}$ & $460-1600$ \\
\hline Гравитационные & обвалы, осыпи & крутые склоны, уступы & $460-1600$ \\
\hline $\begin{array}{l}\text { Блокового } \\
\text { сползания }\end{array}$ & оползни, осовы & $\begin{array}{l}\text { крутые склоны в местах развития } \\
\text { рыхлых отложений }\end{array}$ & $500-700$ \\
\hline $\begin{array}{l}\text { Плоскостного } \\
\text { размыва }\end{array}$ & \begin{tabular}{|l} 
плоскостная \\
эрозия
\end{tabular} & склоны различной крутизны & $500-1000$ \\
\hline $\begin{array}{l}\text { Линейного } \\
\text { размыва }\end{array}$ & овражная эрозия & $\begin{array}{l}\text { пологие склоны в местах } \\
\text { развития рыхлых отложений }\end{array}$ & $460-800$ \\
\hline Абразионные & абразия & береговые уступы оз. Байкал & $450-500$ \\
\hline Дефляционные & $\begin{array}{l}\text { дефляция, } \\
\text { корразия }\end{array}$ & повсеместно & $500-1000$ \\
\hline Аккумулятивные & $\begin{array}{l}\text { площадная } \\
\text { аккумуляция }\end{array}$ & $\begin{array}{l}\text { долины рек в нижнем течении, } \\
\text { дельты }\end{array}$ & $460-500$ \\
\hline $\begin{array}{l}\text { Эрозии рек } \\
\text { и временных } \\
\text { водотоков } \\
\end{array}$ & $\begin{array}{l}\text { глубинная и } \\
\text { боковая эрозия }\end{array}$ & $\begin{array}{l}\text { долины рек и временных } \\
\text { водотоков }\end{array}$ & $460-900$ \\
\hline $\begin{array}{l}\text { Денудации } \\
\text { растворимых } \\
\text { пород } \\
\end{array}$ & карст & Приольхонское плато & $500-900$ \\
\hline $\begin{array}{l}\text { Денудации } \\
\text { нерастворимых } \\
\text { пород } \\
\end{array}$ & суффозия & $\begin{array}{l}\text { предгорья приморского хребта } \\
\text { и локальные очаги } \\
\text { на Приольхонском плато }\end{array}$ & $500-700$ \\
\hline
\end{tabular}


Территория полигона-трансекта выделяется сильным вертикальным эрозионным расчленением, что при ярко выраженной литоморфности подстилающего субстрата и слабой связанности рыхлых отложений, а также на фоне семиаридных и аридных климатических условий обусловливает высокую потенциальную опасность эрозии [Баженова, Мартьянова, 2004]. Существенное влияние на развитие и площадных, и линейных эрозионных процессов оказывают длина и форма склонов, их солярная экспозиция.

\section{Почвенный покров}

Сложившиеся представления о почвенном покрове Приольхонья весьма противоречивы. Во многих работах рассматриваются закономерности пространственной дифференциации почв и почвенного покрова [Цыбжитов и др., 1999; Кузьмин. 2002; Снытко, Данько, 2004; Данько, 2009 и др.]. Она связана с экспозиционными эффектами, геоморфологическими условиями, чередованием более и менее устойчивых к выветриванию почвообразующих горных пород и характером растительного покрова. Существенная роль принадлежит также антропогенному фактору [Кузьмин, Данько, 2011].

Структура почвенного покрова полигона представлена почвенными мезокомбинациями или повторяющимися крупными элементами почвенных ареалов с их микрокомбинациями [Фридланд, 1972]. Мезокомбинации имеют вытянутоконтурную форму и образуют в пределах полигона основные сочетания. Выделяется 2 типа сочетаний: южное и северное. Чередования мезокомбинаций, преобладающие на склонах, составляет контрастные комплексы и слабоконтрастные пятнистости - микрокомбинации. В работе использована классификация почв 2004 г. [Классификация... 2004], но иногда проводятся сравнения с предыдущей классификацией.

Для склонов южной экспозиции на полигоне-трансекте отмечается в целом слабоконтрастная структура почвенного покрова. На крутых $\left(15-25^{\circ}\right)$ и очень крутых $\left(25-40^{\circ}\right)$ приводораздельных склонах со скальными обнажениями и обрывами в основном формируются почвы с маломощным не дифференцированным хрящевато-щебнистым или щебнистым профилем, со слабогумусированным серовато-желтым или серовато-светлобурым бесструктурным супесчаным горизонтом мощностью 3-5 см, насыщенным корнями. Плотная горная порода начинается с глубины уже около 10 см. В классификации эти почвы можно относить к отделу - слаборазвитые, типу - петроземы гумусовые, подтипу — типичные. Отличием профиля, развитого на выходах плотных карбонатных пород, являются карбонатные пленки и бородки на нижней поверхности обломков пород - петроземы гумусовые натечно-карбонатные. На очень крутых участках часто отмечается наличие щебенистого или щебенисто-глыбистого горизонта с минеральным или органоминеральным мелкоземом в качестве заполнителя.

В средней и нижней частях южных склонов с выходами коренных горных пород мощность почвенного профиля возрастает до 15-20, реже до $30 \mathrm{~cm}$. Мощность слабогумусированного желто-серого или буровато-серого бесструктурного супесчаного или песчаного горизонта не превышает 10 см. Для почв характерна высокая (порой до 60\%) щебнистость и хрящеватость. Дифференциация по окраске часто не выражена (рис. 4). Такие почвы относятся к литоземам светлым или светлогумусовому подтипу типичных. 


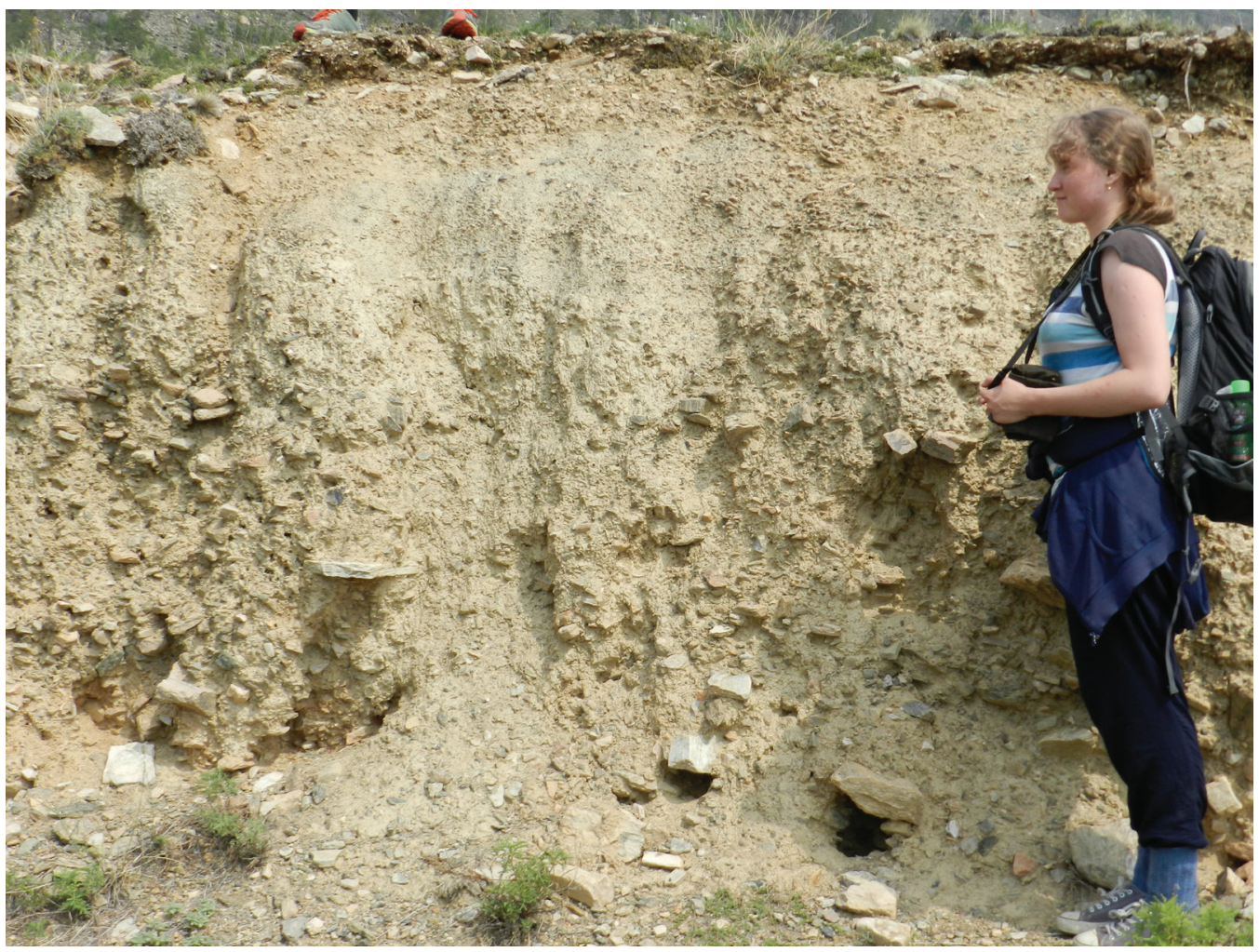

Puc. 4. Показательный разрез почв и подстилающих рыхлых отложений для нижних частей южных склонов, представленных в основном активно развивающимися делювиальными плащами, которые часто подвержены тектоническим деформациям, в связи с чем нормальный процесс формирования почвенного слоя на них периодически прерывается (фото С. Б. Кузьмина)

Похожая ситуация наблюдается на среднекрутых (7-15²) коротких и узких южных склонах прибрежной полосы. На всем протяжении здесь представлены петроземы гумусовые в сочетании с выходами коренных пород, перекрытые щебнистым или щебнисто-глыбистым материалом с минеральным или органоминеральным мелкоземом.

Почвы южных склонов средней крутизны на полигоне отличает слабодифференцированный профиль с серым или буровато-серым слабо задернованным супесчаным горизонтом с непрочно-комковато-порошистой структурой с включениями хряща и щебня до 20-30\%, мощностью 5-7 см (редко до 10 см). Он залегает на слабовыветрелом рыхлом щебнистом (40-60 \%) субстрате различного состава, со слабыми признаками или отсутствием педогенеза, с плотной породой на глубине 40 см. В нижней части этих южных склонов развивается профиль, мощность которого увеличивается до 50-60 см, с гумусово-аккумулятивным слабо задернованным горизонтом не более 10-12 см. Почвы можно отнести к отделу органоаккумулятивных, типу светлогумусовых. На пологих склонах часто формируется аналогичный почвенный профиль (рис. 5), но с более развитым серогумусовым рыхлым супесчаным легкосуглинистым средне задернованным горизонтом с непрочной комковато-порошистой структурой. Прежде подобные почвы относились к дерновым степным или дерновым остепненным. 


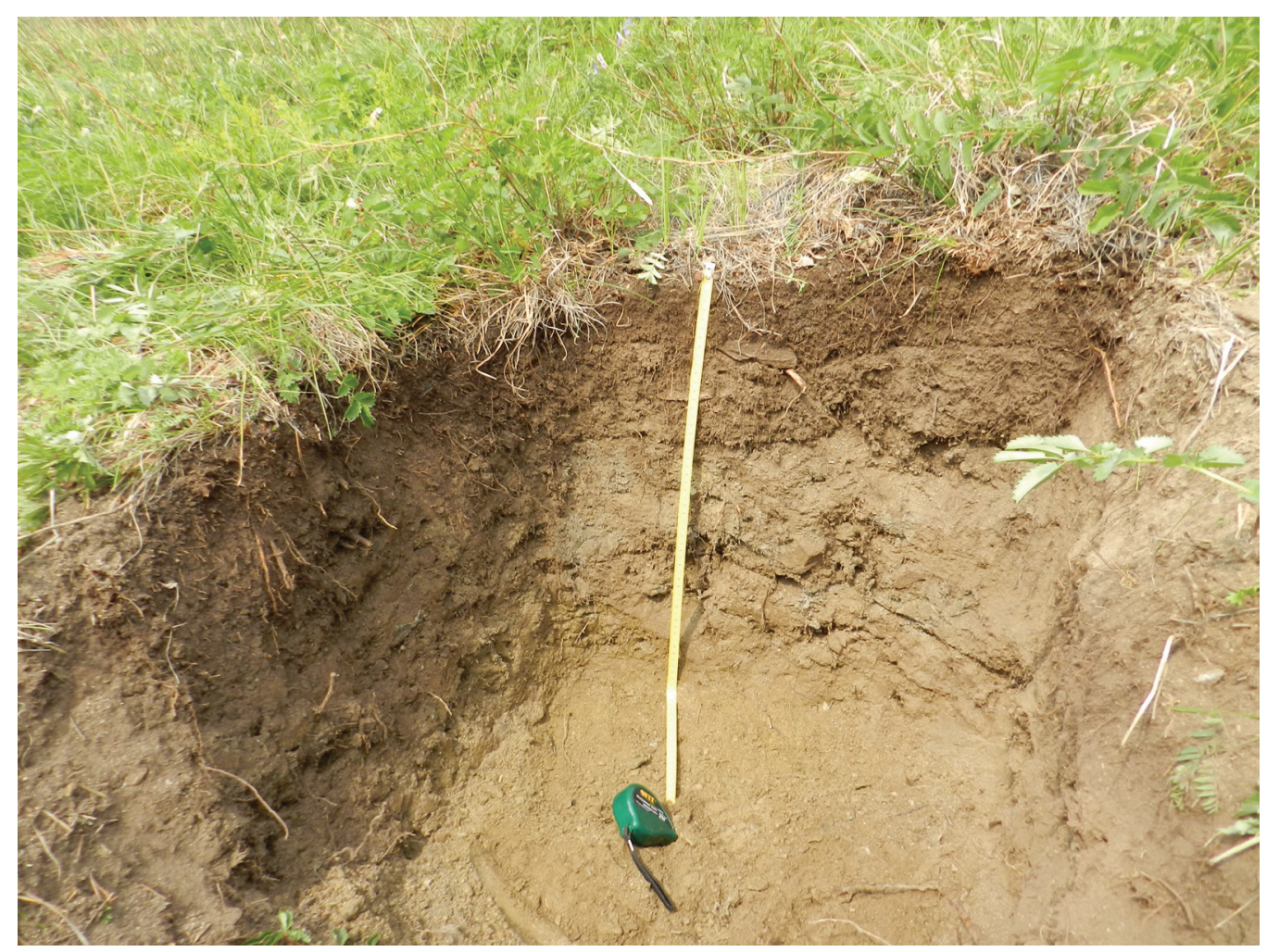

Puc. 5. Почвы, типичные для нижней части пологих южных склонов (фото С. Б. Кузьмина)

Характерной особенностью северных склонов полигона является высокая контрастность почвенного покрова. Приводораздельным склонам свойственна литогенно-эрозионная пятнистость. На обрывистых $\left(>40^{\circ}\right)$ и очень крутых привершинных склонах с выходами скальных пород и каменистыми россыпями на грубом элювии обычно фрагментарно развит органогенный горизонт мощностью 1-3 см разной степени разложения (не выше 50\%) с остатками зеленых мхов разного ботанического состава. Горизонт залегает на песчано-щебенистом мелкоземе мощностью до 3-5 см, прокрашенном органическим веществом в верхней части, подстилаемом плотной, реже рыхлой породой. Подобные почвы относятся к слаборазвитым петроземам типичным (потечно-гумусовым?). На менее крутых участках мощность песчаной толщи возрастает до 7-10 см и снижается каменистость. Ее верхняя часть приобретает слабые признаки оподзоливания в виде рассеянных отмытых зерен минералов, что позволяет классифицировать такие почвы как петроземы типичные оподзоленные.

Ложбины стока и вогнутые элементы приводораздельных склонов заняты маломощными щебенистыми сильно скелетными почвами. Их профиль обычно включает органогенный горизонт (1-2 см) и гумусово-аккумулятивный буровато-серый, часто до черного с буроватым оттенком горизонт (5-7 см). Почвенный профиль в целом супесчаный, слабо задернованный (2-4 cм) с непрочной комковатой структурой. Содержание щебня в нем достигает 30-40 \%. В классификации 2004 г. выделения таких почв нет, а наиболее близки к ним петроземы гумусовые. 
К средней части северных склонов приурочены слаборазвитые почвы из органогенного горизонта (1-2 см) и серого, серовато-бурого (иногда черного с бурым оттенком) гумусово-аккумулятивного горизонта (10-15 см) обычно с непрочной комковатой или комковато-порошистой структурой. Под ним залегает в основном маломощный (до 10 см) переходный горизонт, нередко насыщенный мелкоземом желтых и желтовато-охристых оттенков, реже с желто-охристыми пленками на поверхности включенного щебня. Мощность преобразованной почвообразованием толщи нигде не превышает даже 30 см (рис. 6). Такие почвы можно отнести к литоземам серогумусовым (дерновым), к подтипам типичные и иллювиально-ожелезненные.

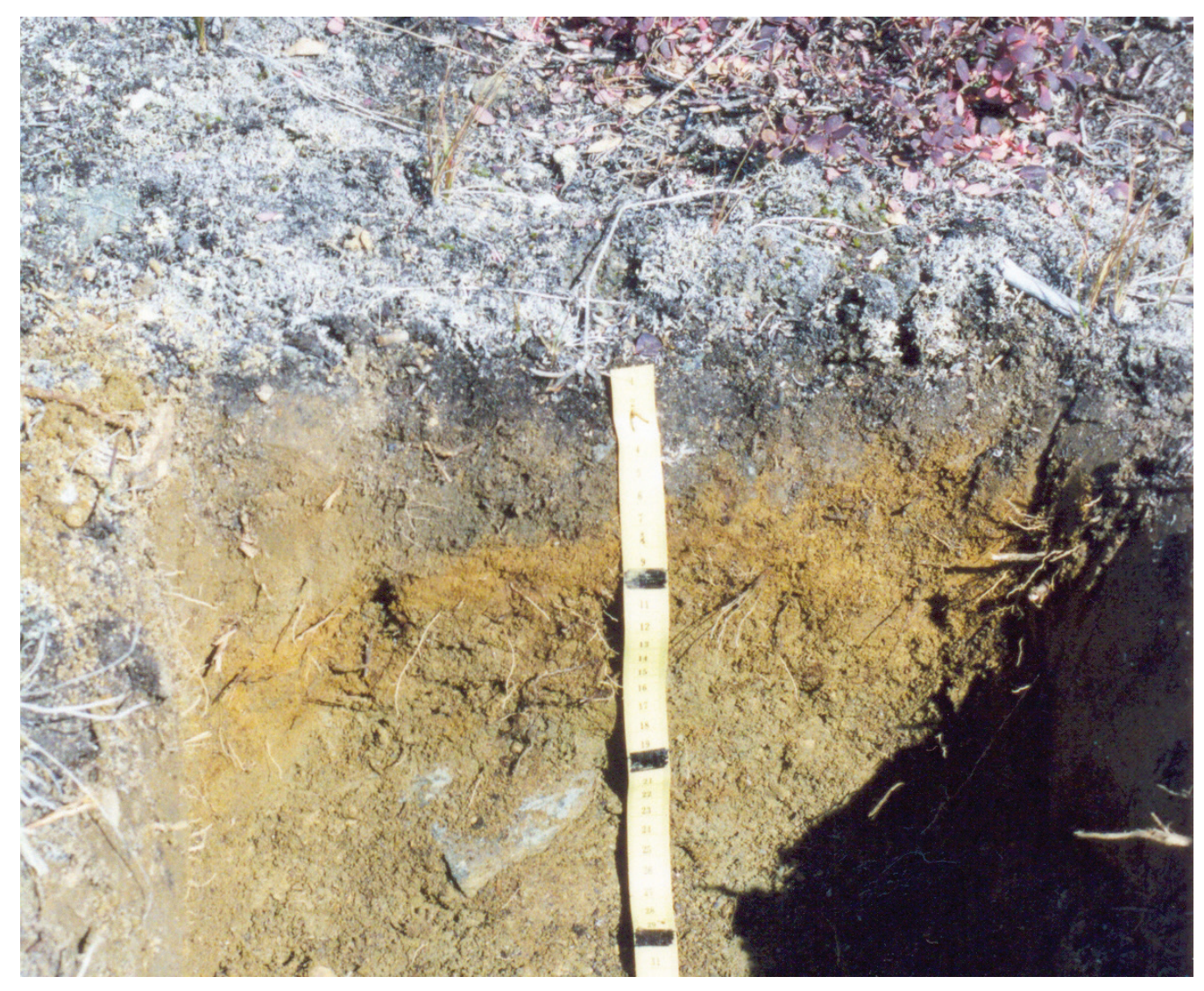

Puc. 6. Типичные почвы полигона для подгольцовых и средних участков склонов северной экспозиции, в основном средней крутизны, но иногда — пологих (фото С. Б. Кузьмина)

Ниже по северным склонам, ближе к подножью, описанные почвы сменяют почвы со слабодифференцированным профилем, который постепенно переходит к плотной горной породе, которая на всех изученных участках залегает не ближе чем в 50 см от поверхности. Мощность таких почв может достигать 40-50 см и даже доходить до 70-80 см (рис. 7). В целом их профиль состоит из лесной подстилки (1-2 см), гумусово-аккумулятивного темно-серого с бурым оттенком супесчаного или легкосуглинистого опесчаненного горизонта (мощностью 10-15 см) с комковато-порошистой структурой и минерального слабоструктурного 
горизонта различной окраски с присутствием бурых тонов, который постепенно принимает более светлую окраску при переходе к коренной горной породе. Верхние 3-5 см гумусово-аккумулятивного горизонта сильно задернованы. Содержание дресвы и щебня, как правило, заметно увеличивается вниз по профилю - от 20-30 до 40-60\%. Такие почвы согласно классификации относятся к отделу органо-аккумулятивных, типу серогумусовых (дерновых).

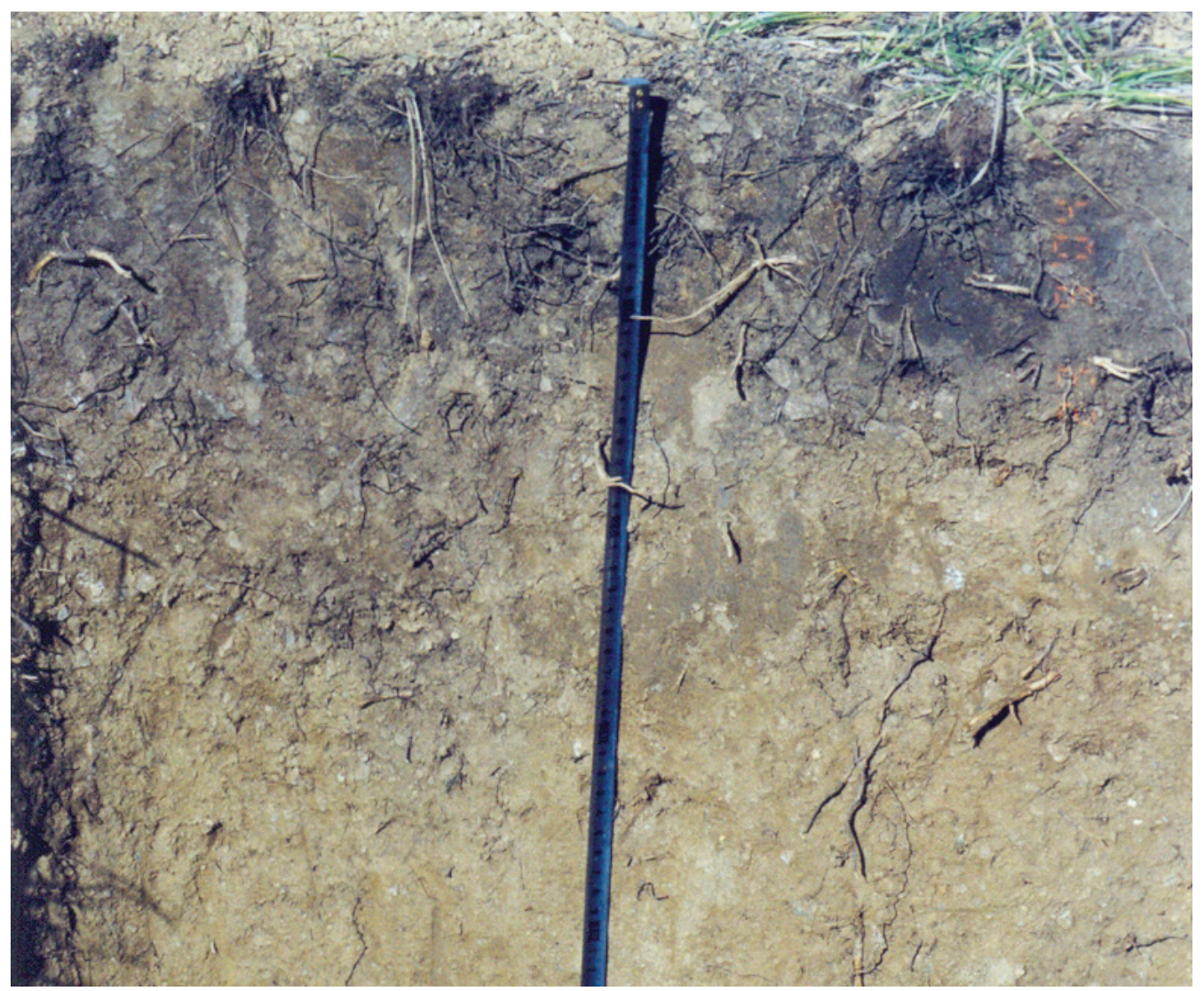

Рис. 7. Типичные почвы полигона в нижних частях в основном пологих северных склонов, представленных преимущественно мелкообломочными делювиальными шлейфами, реже - конусами выноса (фото С. Б. Кузьмина)

Для северных склонов средней крутизны характерна смена литоземов серогумусовых в приводораздельной части на органо-аккумулятивные серогумусовые, приуроченные к подножью склонов и ложбинам стока.

На выположенных поверхностях различного генезиса с плотными карбонатными породами формируется маломощный (5-10 см, редко до 20-30 см) почвенный профиль с рыхлым супесчаным гумусовым горизонтом с окраской от светлосерой или палево-серой до темно-серой, со слабо выраженной непрочно-комковатопорошистой структурой, который часто содержит не оформленные в новообразования карбонаты и остаточные «породные» карбонаты. Содержание щебня в профиле таких почв варьирует от 20-30 до 60-80\%. Ранее они выделялись как горные 
степные карбонатные. Согласно классификации 2004 г., почвы с менее развитым профилем относят к карбо-петроземам гумусовым, а вторым отчасти соответствует подтип типичных карбо-литоземов темногумусовых, но гумусовой горизонт диагностируется как светлогумусовый.

Почвенный покров выположенных широких суходолов и мелких блюдцеобразных котловин представлен, как правило, гетерохронными стратифицированными почвами, формирующимися на разновозрастных рыхлых отложениях. В связи с этим требуются специальные, более детальные их исследования, опирающиеся на комплекс палеогеографических методов, что позволит разделить современные и экспонированные древние почвы, выделить погребенные и переотложенные горизонты.

Влияние хозяйственной деятельности на почвенный покров полигона приводит к резкой активизации экзогенных геоморфологических процессов и резко усиливает процессы его дегумификации. В этом кроется причина распространения на северных склонах полигона-трансекта почв со слаборазвитым светлогумусовым горизонтом: петроземов гумусовых и органо-аккумулятивных светлогумусовых. Участие таких преобразованных почв в структуре почвенного покрова северных склонов заметно возрастает по всему Приольхонскому плато, на юго-восточном борту Кучелго-Таловской депрессии, склонах северной экспозиции, прибрежных участках оз. Байкал, т. е. именно в тех местах, где отмечены наиболее продолжительные и интенсивные антропогенные нагрузки на ландшафты.

Для южных склонов главным следствием хозяйственной деятельности является широкое распространение на среднекрутых склонах литоземов светлогумусовых с хрящевато-щебенистым органоминеральным мелкоземом. На пологих склонах представлены органо-аккумулятивные светлогумусовые почвы со слаборазвитым (5-7 см, редко 10 см) гумусовым горизонтом в сочетании с почвами, профиль которых состоит из гумусово-слаборазвитого горизонта (2-5 см), залегающего непосредственно на песчаных отложениях (классифицируются как псаммоземы гумусовые).

\section{Растительный покров}

Растительный покров Приольхонья изучался многими авторами [Моложников, 1986; Касьянова, 1993; Пешкова, 2001; Экологически... 2004; Сизых, 2015 и др.]. Основным фактором пространственной неоднородности растительного покрова считается рельеф, а также геоморфологические процессы, особенности почв и процессов почвообразования. Наибольшие различия имеют растительные сообщества юго-восточных и северо-западных склонов. Смена геоморфологических условий на склонах разной экспозиции в сочетании с изменениями литоморфности и степени увлажнения геологического субстрата обусловливает формирование ряда последовательно сменяющих друг друга растительных сообществ и особенностей их состава.

На полигоне особенности структуры растительности остепненных южных склонов в зависимости от литолого-геоморфологических условий отражают следующий ряд степных сообществ - ассоциаций: 1) карагановая петрофитноразнотравно-типчаковая водораздельных гребней и очень крутых выпуклых приводораздельных склонов; 2) петрофитно-разнотравная типчаково-хамеродосовая 
с караганой денудационных поверхностей верхней части склона; 3) петрофитноразнотравно-мелкодерновинно-злаковая крутых склонов; 4) разнотравная осоковотипчаковая среднекрутых склонов; 5) разнотравно-злаковая подножий и пологих склонов (рис. 8).

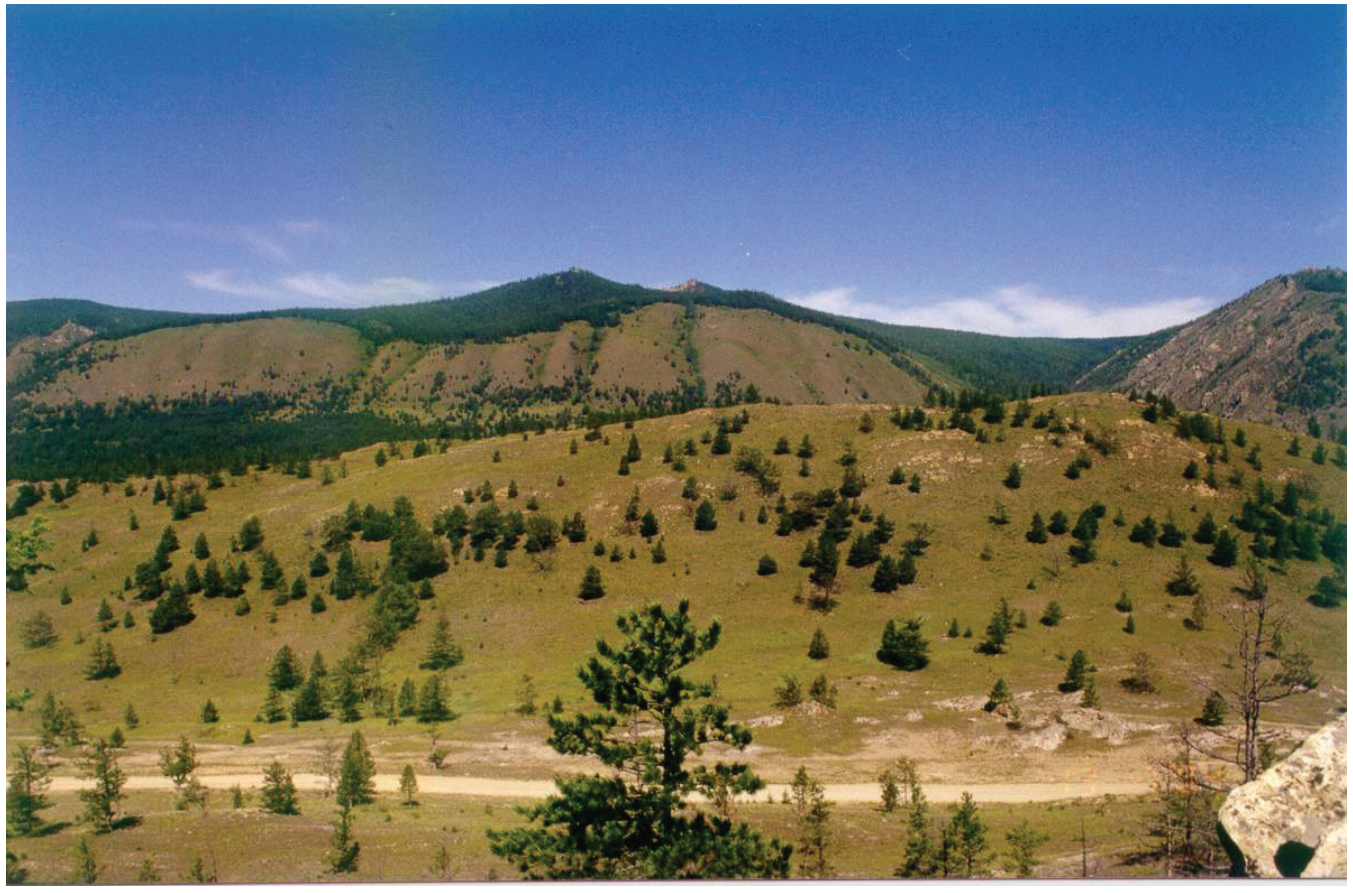

Puc. 8. Степи, лесостепи и остепненные редколесья - типичная растительность южных склонов на полигоне (фото С. Б. Кузьмина)

Для северных склонов характерен иной ряд растительных ассоциаций по мере снижения литоморфности условий: 1) кустарниковая с лиственницей петрофитно-разнотравно-типчаковая с караганой водораздельных гребней; 2) лиственничная редина кустарниковая зеленомошно-осоковая с разнотравьем очень крутых выпуклых приводораздельных склонов; 3) лиственничная редкостойная разнотравно-мелкодерновинно-злаковая с синузиями зеленых мхов денудационных поверхностей верхней части склона; 4) лиственничная разреженная обычно с рододендроном даурским осоково-зеленомошная с разнотравьем крутых склонов; 5) лиственничная разреженная с кизильником зеленомошно-разнотравно-осоковая в основном среднекрутых склонов; 6) лиственничная с кизильником осоковоразнотравно-злаковая с синузиями зеленых мхов подножий и пологих склонов (рис. 9).

Для территории всего полигона-трансекта внутри фитоценозов каждой растительной ассоциации присутствуют ценозы, характерные для других ассоциаций, что создает некоторую мозаичность. а нередко и комплексность растительного покрова. Основным фактором формирования мозаичности являются выходы скальных горных пород, особенно в инсолируемых местоположениях, а также специфический микрорельеф, обусловливающий существенную неоднородность увлажнения геологического субстрата. 


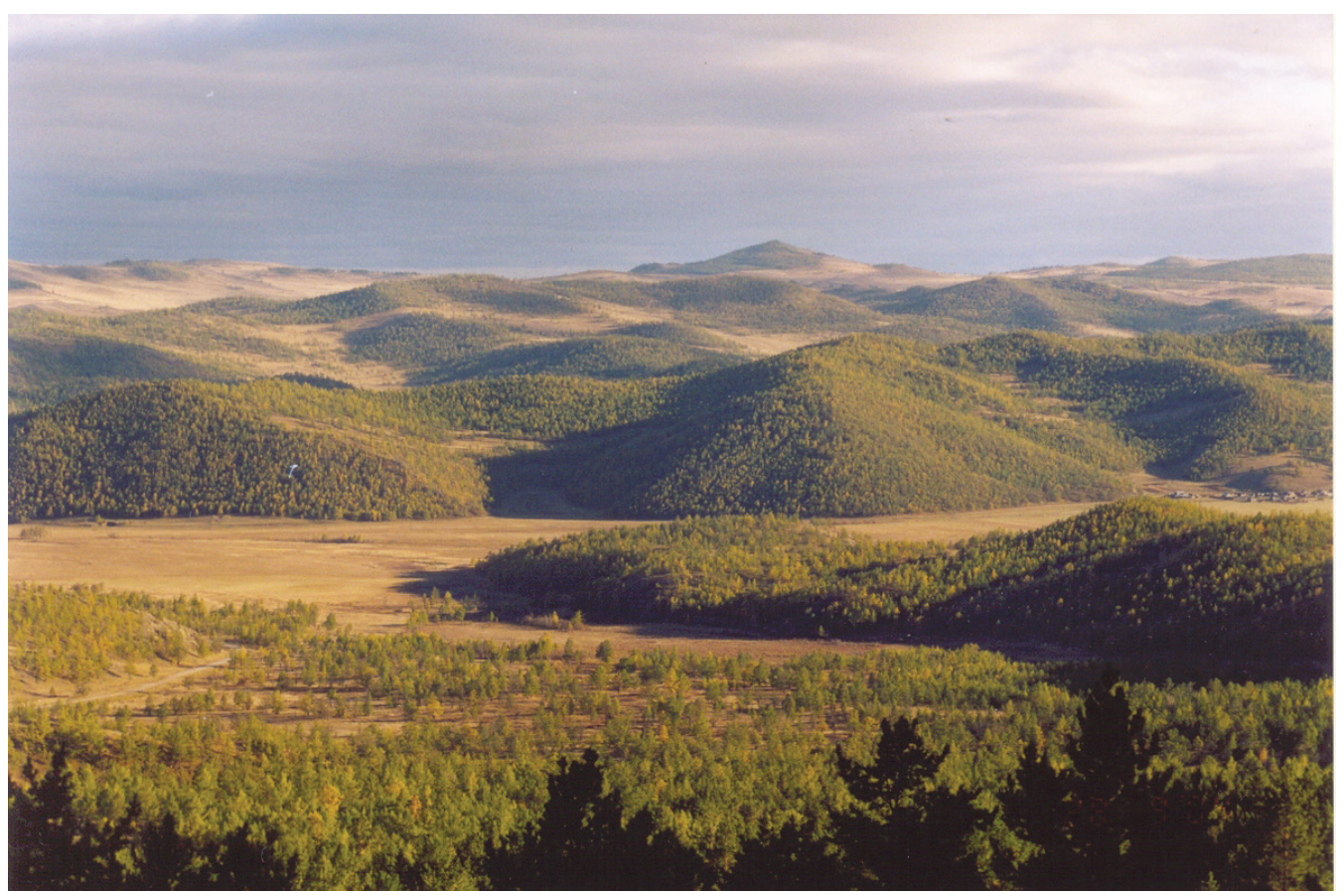

Рис. 9. Типичная растительность северных склонов полигона (фото С. Б. Кузьмина)

Влияние микрорельефа на растительность полигона особенно сильно проявляется на водоразделах и в верхней части склонов, а также на сильно денудированных поверхностях. Наличие линейно вытянутых структурных грив и гряд, формирующихся в связи с различной устойчивостью горных пород к выветриванию, определяет неоднородный спектр травостоя. На гривах и грядах травостой обычно сильно разрежен, с невыраженной ярусностью, слагается в основном овсяницей ленской и петрофитным разнотравьем, в котором на южных склонах доминирует главным образом хамеродос алтайский, а на северных — астрагал разноцветный (рис. 10).

Другой причиной пятнистости сложения степного разнотравья является высокая хрящеватость и щебнистость геологического субстрата, на котором оно произрастает, при его незначительной мощности на крутых выпуклых элементах склонов, где возрастает литоморфность условий, с одной стороны, и сухость с другой. Так, в сообществах остепненных лиственничников на склонах всех экспозиций усиление литоморфности условия произрастания предопределяет увеличение обилия осоки стоповидной, полыни холодной, эдельвейса обыкновенного, гетеропаппуса алтайского и др. Одновременно усиление ксероморфности условий определяет широкое распространение, а на южных склонах - доминирование ксерофитов и криоксерофитов: полыни холодной, вероники седой, перистоволостника тонколистного, хамеродоса прямостоячего и др. Повышенная засушливость условия произрастания характерна и для участков карстующихся карбонатных пород, а наиболее сильно выражена она на выходах собственно известняков.

Значительные изменения характера растительности можно отметить и по направлению от предгорий Приморского хребта к берегу основной котловины 
о3. Байкал по всему простиранию полигона-трансекта. Так, при безусловном доминировании голарктических бореальных и южно-сибирских элементов флоры возрастает доля восточноазиатских и центральноазиатских видов растений. Например, у самого побережья оз. Байкал более заметным становится присутствие североазиатских видов, особенно в структуре фитоценозов обрывистых береговых сильно продуваемых склонов.

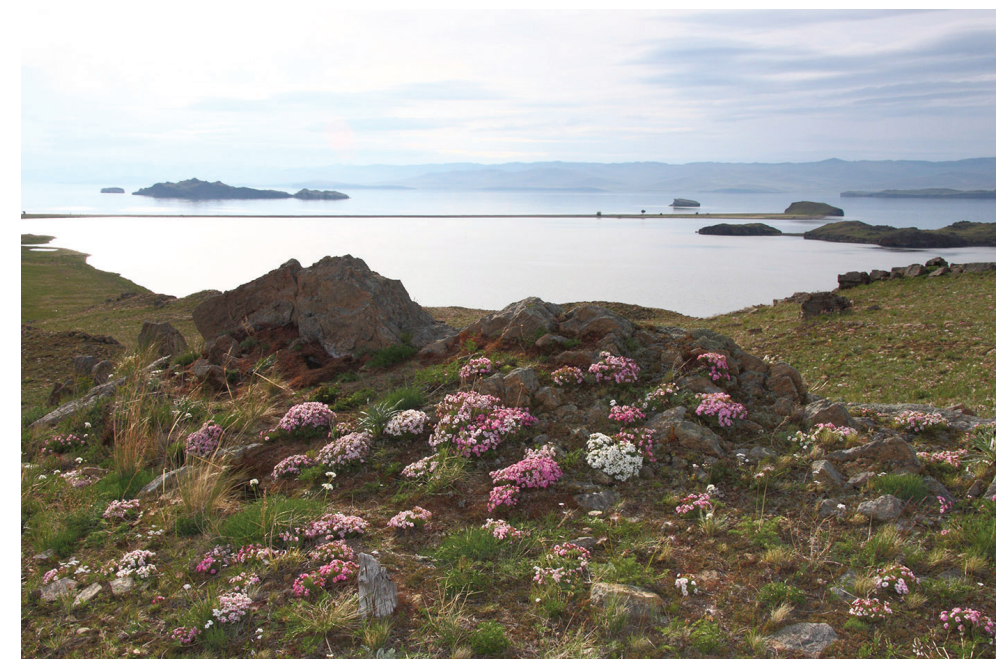

A

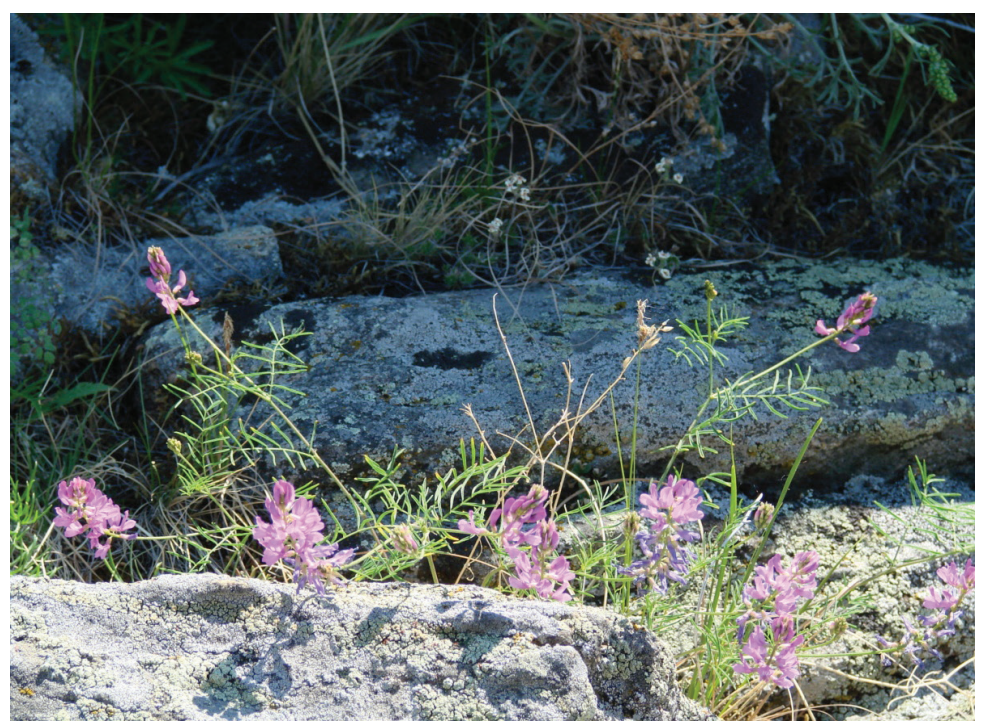

Б

Рис. 10. А. Хамеродос алтайский, Chamaerhodos altaica (Laxm.) Bunge (семейство Rosaceae) на мелких гривах южных склонов в районе мыса Уюга у подножья Приморского хребта (фото Виктора Баяндина с сайта https://www.plantarium.ru/page/image/id/166906.html). Б. Астрагал разноцветный, Astragalus versicolor Pall. (семейство Fabaceae) среди развалов камней на северных склонах Приольхонского плато к северо-западу от поселка Сахюрта - MPC (фото Людмилы Паламарчук с сайта https://www.plantarium.ru/page/ image/id/553939.html) 


\section{Ландшафтная структура}

В ландшафтной структуре на полигоне-трансекте по макропрофилю нами выделено 19 фаций. Они в пределах единого элемента микрорельефа — морфоскульптуры - составляют урочища, которые в границах морфоструктур объединены в местности. Урочища северных склонов состоят из 2-3 фаций, южных склонов, днищ долин и понижений - одной (рис. 11, табл. 2).

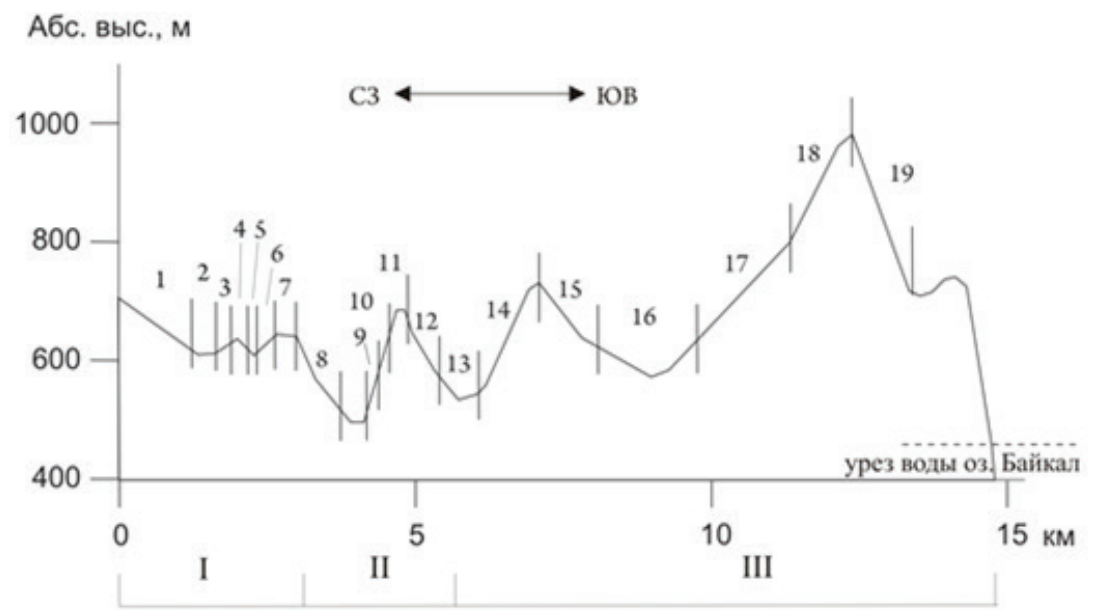

Puc. 11. Ландшафтная структура Приольхонья вдоль макропрофиля на полигоне-трансекте. Объяснения номеров см. в Табл. 2. I - предгорья Приморского хребта, II - КучелгоТаловская депрессия, III — Приольхонское плато

Таблица 2

Структура ландшафтов полигона-трансекта

\begin{tabular}{|c|c|c|c|}
\hline \multicolumn{4}{|c|}{ Выделы ландшафтов топологической размерности } \\
\hline Местности & Урочища & Фации & Номера \\
\hline \multirow[t]{7}{*}{$\begin{array}{l}\text { Предгорья } \\
\text { Приморского } \\
\text { хребта }\end{array}$} & $\begin{array}{l}\text { предгорный южный } \\
\text { делювиальный склон (шлейф) } \\
\text { с петроземами гумусовыми } \\
\text { типичными слаборазвитыми } \\
\end{array}$ & сосновая разнотравная & 1 \\
\hline & \multirow[t]{2}{*}{$\begin{array}{l}\text { предгорный прогиб с органо- } \\
\text { аккумулятивными светло- } \\
\text { гумусовыми почвами }\end{array}$} & $\begin{array}{l}\text { сосново-лиственничная } \\
\text { осоково-разнотравная } \\
\text { с зелеными мхами } \\
\end{array}$ & 2 \\
\hline & & $\begin{array}{l}\text { лиственничная с сосной } \\
\text { кустарниковая зеленомошно- } \\
\text { осоковая }\end{array}$ & 3 \\
\hline & \multirow{4}{*}{$\begin{array}{l}\text { предгорное компенсационное } \\
\text { поднятие с карбо-петроземами } \\
\text { гумусовыми и карбо- } \\
\text { литоземами темногумусовыми }\end{array}$} & $\begin{array}{l}\text { лиственничная разреженная } \\
\text { разнотравная с кустарниками }\end{array}$ & 4 \\
\hline & & $\begin{array}{l}\text { лиственничная редкостойная } \\
\text { осоково-разнотравная }\end{array}$ & 5 \\
\hline & & $\begin{array}{l}\text { лиственничная редкостойная } \\
\text { кустарниковая разнотравно- } \\
\text { осоковая с зелеными мхами } \\
\end{array}$ & 6 \\
\hline & & $\begin{array}{l}\text { петрофитная разнотравная } \\
\text { с лиственницей }\end{array}$ & 7 \\
\hline
\end{tabular}


С. Б. Кузьмин, С. И. Шаманова. Ландшафтная структура Приольхонья

\begin{tabular}{|c|c|c|c|}
\hline \multicolumn{4}{|c|}{ Выделы ландшафтов топологической размерности } \\
\hline Местности & Урочища & Фации & Номера \\
\hline \multirow[t]{4}{*}{$\begin{array}{l}\text { Кучелго- } \\
\text { Таловская } \\
\text { депрессия }\end{array}$} & $\begin{array}{l}\text { южный склон с карбо- } \\
\text { петроземами гумусовыми } \\
\text { типичными слаборазвитыми }\end{array}$ & $\begin{array}{l}\text { лиственничная редкостойная } \\
\text { разнотравная }\end{array}$ & 8 \\
\hline & $\begin{array}{l}\text { днище котловины с органо- } \\
\text { аккумулятивными темно- } \\
\text { гумусовыми почвами }\end{array}$ & $\begin{array}{l}\text { лиственничная редкостойная } \\
\text { злаково-разнотравная }\end{array}$ & 9 \\
\hline & \multirow[t]{2}{*}{$\begin{array}{l}\text { северный склон } \\
\text { с петроземами типичными } \\
\text { потечно-гумусовыми }\end{array}$} & $\begin{array}{l}\text { лиственничная кустарниковая } \\
\text { разнотравно-осоково- } \\
\text { зеленомошная }\end{array}$ & 10 \\
\hline & & $\begin{array}{l}\text { лиственничная разреженная } \\
\text { кустарниковая петрофитная } \\
\text { разнотравная }\end{array}$ & 11 \\
\hline \multirow[t]{8}{*}{$\begin{array}{l}\text { Приольхонское } \\
\text { плато }\end{array}$} & \multirow[t]{2}{*}{$\begin{array}{l}\text { южный склон с петроземами } \\
\text { гумусовыми типичными } \\
\text { слаборазвитыми }\end{array}$} & $\begin{array}{l}\text { лиственничная } \\
\text { разреженная кустарниковая } \\
\text { злаково-разнотравная } \\
\end{array}$ & 12 \\
\hline & & $\begin{array}{l}\text { лиственничная разреженная } \\
\text { разнотравно-злаковая }\end{array}$ & 15 \\
\hline & \multirow{2}{*}{$\begin{array}{l}\text { днища котловин и } \\
\text { плоскодонных распадков } \\
\text { с органо-аккумулятивными } \\
\text { светло-гумусовыми почвами }\end{array}$} & $\begin{array}{l}\text { злаково-разнотравная } \\
\text { с лиственницей }\end{array}$ & 13 \\
\hline & & $\begin{array}{l}\text { злаково-разнотравная } \\
\text { с лиственницей и сосной }\end{array}$ & 16 \\
\hline & $\begin{array}{l}\text { северный склон } \\
\text { с петроземами типичными } \\
\text { потечно-гумусовыми } \\
\end{array}$ & $\begin{array}{l}\text { лиственничная кустарниковая } \\
\text { осоково-разнотравная }\end{array}$ & 14 \\
\hline & \multirow{2}{*}{$\begin{array}{l}\text { северный склон с литоземами } \\
\text { серо-гумусовыми (дерновыми) } \\
\text { типичными и иллювиально- } \\
\text { ожелезненными }\end{array}$} & $\begin{array}{l}\text { лиственничная разреженная } \\
\text { злаково-разнотравная } \\
\end{array}$ & 17 \\
\hline & & \begin{tabular}{|l} 
лиственничная с сосной \\
рододендровая петрофитная \\
зеленомошно-осоковая \\
\end{tabular} & 18 \\
\hline & $\begin{array}{l}\text { южный склон с литоземами } \\
\text { светлогумусовыми типичными }\end{array}$ & $\begin{array}{l}\text { каменисто-скальная } \\
\text { разнотравно-злаковая } \\
\text { с сосной }\end{array}$ & 19 \\
\hline
\end{tabular}

Выделенные фации имеют различную значимость в ландшафтной структуре. Фации, большие площади и создающие ландшафтный облик урочищ относятся к основным. Они обычно простираются вдоль склона до первых сотен метров полосой шириной 20-50 м (реже 100 м) и сменяют друг друга вверх по склону, образуя высотную фациальную «микропоясность». Второстепенными являются фации, занимающие отдельные микроформы рельефа: гривы, гребни, ложбины стока, микрозападины и т. п.

В предгорьях Приморского хребта и на пологих склонах Кучелго-Таловской депрессии преобладают разреженные лиственничные и сосново-лиственничные кустарниковые леса с зеленомошно-осоковым и осоково-разнотравным травянистым покровом, нередко с участием степных видов - астрагал разноцветный, полынь холодная. Здесь лесные фации контактируют со степными, образуя экотон горной тайги и степи. Причем степные фации распространены преимущественно на южных и юго-восточных склонах Кучелго-Таловской депрессии и, в меньшей 
степени, предгорий Приморского хребта. Растительность степных участков представлена мелкодерновинно-злаковыми и низкоразнотравными с полынью сообществами с участием кустарников в основном в сочетании со злаковым разнотравьем. Широкое распространение степной растительности в пределах всей центральной части Приольхонья связано с влиянием хозяйственной деятельности человека: выпас скота, рубки, пожары на протяжении по крайней мере последних 2000 лет, но особенно активно в XIX-XX веках. Тем не менее в последнее время в связи со снижением антропогенной нагрузки на ландшафты (с конца XX века в связи с развалом СССР, экономики региона и последующим ужесточением законодательства России в плане охраны природы оз. Байкал) наблюдаются активные процессы восстановительной динамики, и остепненные южные склоны начинают покрываться древостоем (рис. 12, см. также рис. 8).

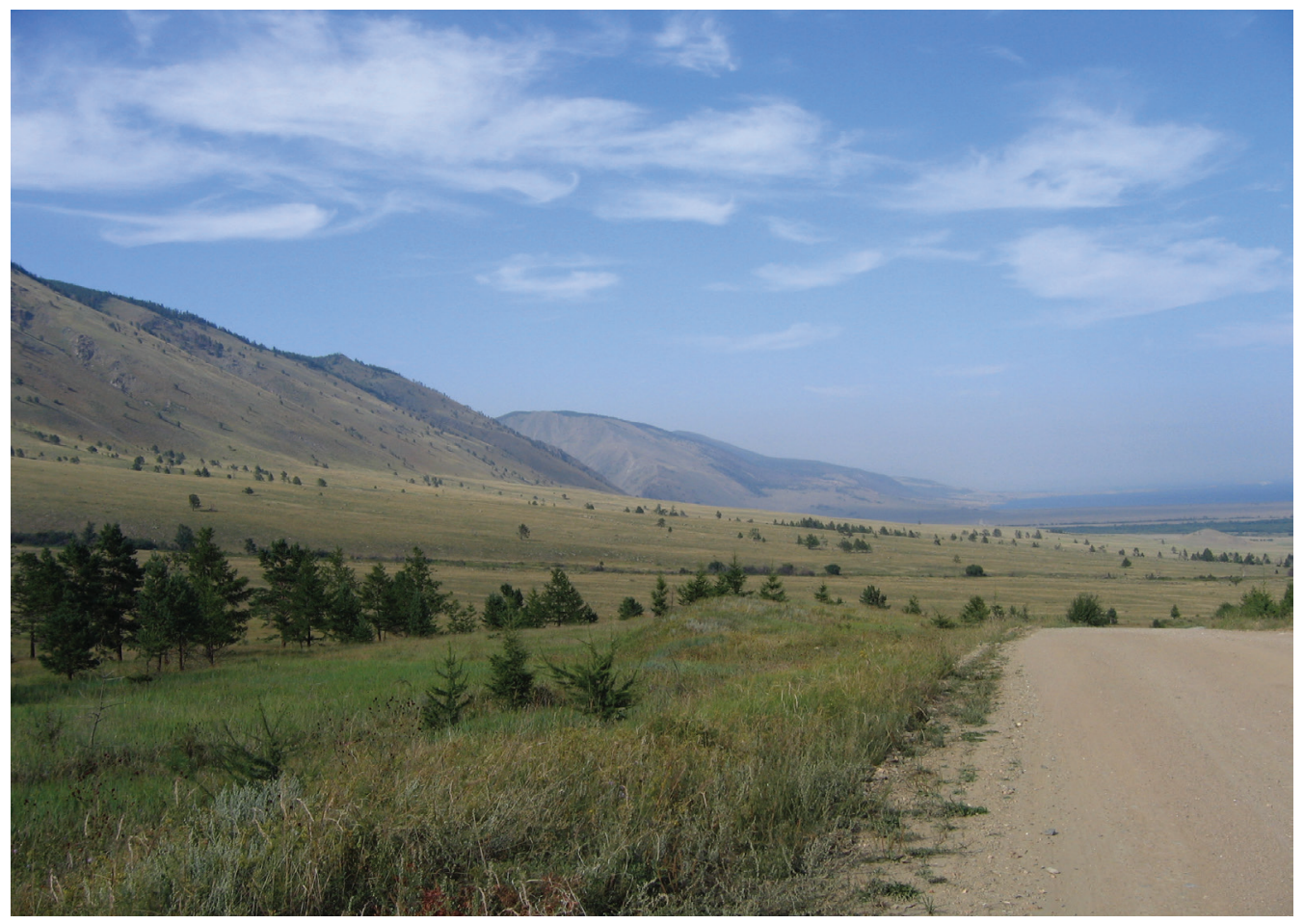

Puc. 12. Восстановление древесной растительности на предгорном пологом склоне Приморского хребта, бывшего ранее полностью безлесным в результате масштабной и глубокой по силе пастбищной дигрессии - традиционные пастбищные угодья бурятских улусов, а с приходом Советской власти - колхоза им. М. В. Фрунзе с 1935 по 1970 г., переименованного в колхоз им. ХХ партсъезда с 1971 по 1992 г. (фото С. Б. Кузьмина)

Влияние геологического субстрата, рельефа и геоморфологических процессов на пространственную структуру ландшафтов наиболее отчетливо выступает на Приольхонском плато. Мезо- и микроклиматические различия, связанные с гипсометрическим положением фаций, микрорельефом и экспозиционными эффектами, незамедлительно сказываются в увлажнении почв и в структуре растительного покрова, сопровождаясь почти всегда усилением роли ксеромезо- и мезофитного разнотравья. 
Растительность, таким образом, является основным индикатором при выделении фаций в ландшафтной структуре Приольхонья. Поэтому для полигонатрансекта в каждой выделенной фации мы провели детальный анализ растительности по элементам рельефа, что позволило дополнительно установить более тонкие детали структурной организации ландшафтов на полигоне-трансекте топологического уровня (табл. 3).

Таблица 3

Характеристика растительности как критерия выделения фаций полигона-трансекта

\begin{tabular}{|c|c|c|c|c|c|}
\hline № & \begin{tabular}{|c|} 
Элемент \\
рельефа, \\
морфо- \\
скульптура \\
\end{tabular} & $\begin{array}{c}\text { Древесный } \\
\text { ярус (состав, } \\
\text { сомкнутость, } \\
\text { подрост) } \\
\end{array}$ & $\begin{array}{c}\text { Кустарниковый } \\
\text { ярус } \\
\text { (видовой } \\
\text { состав) } \\
\end{array}$ & $\begin{array}{c}\text { Моховой покров } \\
\text { (проективное } \\
\text { покрытие, } \\
\text { видовой состав) } \\
\end{array}$ & $\begin{array}{c}\text { Травянисто- } \\
\text { кустарничковый ярус } \\
\text { (виды доминанты) }\end{array}$ \\
\hline 1 & $\begin{array}{c}\text { Ю-В } \\
\text { предгорный } \\
\text { шлейф }\end{array}$ & $\begin{array}{c}9 \mathrm{C}+(\mathrm{O})+1 Л \\
0,6-0,5 \\
л+\mathrm{c}+\text { к (ед) }\end{array}$ & $\begin{array}{c}\text { кизильник } \\
\text { черноплодный, } \\
\text { роза иглистая, } \\
\text { спирея средняя }\end{array}$ & $\begin{array}{c}\text { синузиально. } \\
\text { Дитидиум } \\
\text { морщинистый, } \\
\text { плеврозиум } \\
\text { шребера, } \\
\text { абиетинелла } \\
\text { пихтовая }\end{array}$ & $\begin{array}{c}\text { зопник } \\
\text { клубненосный, } \\
\text { прострел раскрытый, } \\
\text { мятлик кистевидный, } \\
\text { подмаренник } \\
\text { настоящий, полынь } \\
\text { селитряная }\end{array}$ \\
\hline 2 & $\begin{array}{c}\text { C-3 } \\
\text { склон }\end{array}$ & $\begin{array}{c}8 Л+2 \mathrm{C} \\
0,7-0,6 \\
л+\mathrm{c}+\kappa(е д)\end{array}$ & $\begin{array}{c}\text { кизильник } \\
\text { черноплодный, } \\
\text { рододендрон } \\
\text { даурский }\end{array}$ & $\begin{array}{c}\text { синузиально. } \\
\text { Дикранум } \\
\text { многоножковый, } \\
\text { птилиум } \\
\text { гребенчатый, } \\
\text { ритидиум } \\
\text { морщинистый } \\
\end{array}$ & $\begin{array}{c}\text { брусника, осока } \\
\text { длиннохвостая, } \\
\text { подмаренник } \\
\text { настоящий, } \\
\text { подмаренник } \\
\text { северный, } \\
\text { колокольчик сборный }\end{array}$ \\
\hline 3 & $\begin{array}{c}\text { С-3 } \\
\text { приводо- } \\
\text { раздельный } \\
\text { склон, } \\
\text { вершина }\end{array}$ & $\begin{array}{c}9 Л+1 \mathrm{C} \\
0,9-0,8 \\
Л+\kappa+c\end{array}$ & $\begin{array}{c}\text { рододендрон } \\
\text { даурский, } \\
\text { душекия } \\
\text { кустарниковая, } \\
\text { спирея средняя }\end{array}$ & $\begin{array}{c}\text { 80-60\%. } \\
\text { дикранум } \\
\text { многоножковый, } \\
\text { плеврозиум } \\
\text { шребера, } \\
\text { ритидиадельфус } \\
\text { трехрядный } \\
\end{array}$ & $\begin{array}{c}\text { брусника (редко), } \\
\text { осока длиннохвостая, } \\
\text { прострел раскрытый, } \\
\text { колокольчик } \\
\text { Турчининова, мытник } \\
\text { перевернутый }\end{array}$ \\
\hline 4 & $\begin{array}{c}\text { Ю-В } \\
\text { середина } \\
\text { склона }\end{array}$ & $\begin{array}{c}\text { Л } \\
0,3-0,2 \\
\text { л ед. }\end{array}$ & $\begin{array}{c}\text { кизильник } \\
\text { черноплодный } \\
\text { (ед.) }\end{array}$ & - & $\begin{array}{c}\text { овсяница } \\
\text { ленская, осока } \\
\text { стоповидная, зопник } \\
\text { клубненосный, } \\
\text { лапчатка } \\
\text { пижмалистная } \\
\end{array}$ \\
\hline 5 & $\begin{array}{c}\text { С-3 } \\
\text { подножье, } \\
\text { днище }\end{array}$ & $\begin{array}{c}\text { Л + ед. C } \\
0,7-0,5 \\
\pi+\text { ед. с }\end{array}$ & - & - & $\begin{array}{c}\text { осока длиннохвостая, } \\
\text { подмаренник } \\
\text { настоящий, мятлик } \\
\text { кистевидный, } \\
\text { астрагал } \\
\text { разноцветный }\end{array}$ \\
\hline 6 & $\begin{array}{l}\text { C-3 } \\
\text { склон }\end{array}$ & $\begin{array}{c}\text { Л } \\
0,5-0,3 \\
\text { л + ед. к }\end{array}$ & $\begin{array}{c}\text { кизильник } \\
\text { черноплодный, } \\
\text { спирея средняя }\end{array}$ & $\begin{array}{c}\text { синузиально. } \\
\text { Ритидиум } \\
\text { морщинистый, } \\
\text { птилиум } \\
\text { гребенчатый, } \\
\text { плеврозиум } \\
\text { шребера }\end{array}$ & $\begin{array}{l}\text { осока длиннохвостая, } \\
\text { прострел раскрытый }\end{array}$ \\
\hline
\end{tabular}




\begin{tabular}{|c|c|c|c|c|c|}
\hline № & $\begin{array}{c}\text { Элемент } \\
\text { рельефа, } \\
\text { морфо- } \\
\text { скульптура } \\
\end{array}$ & $\begin{array}{c}\text { Древесный } \\
\text { ярус (состав, } \\
\text { сомкнутость, } \\
\text { подрост) } \\
\end{array}$ & $\begin{array}{c}\text { Кустарниковый } \\
\text { ярус } \\
\text { (видовой } \\
\text { состав) } \\
\end{array}$ & $\begin{array}{c}\text { Моховой покров } \\
\text { (проективное } \\
\text { покрытие, } \\
\text { видовой состав) } \\
\end{array}$ & $\begin{array}{c}\text { Травянисто- } \\
\text { кустарничковый ярус } \\
\text { (виды доминанты) }\end{array}$ \\
\hline 7 & $\begin{array}{c}\text { С-3 } \\
\text { приводо- } \\
\text { раздельный } \\
\text { склон } \\
\end{array}$ & $\begin{array}{c}0,1 \\
\text { Л } \\
-\end{array}$ & \begin{tabular}{|c|} 
кизильник \\
черноплодный, \\
карагана \\
карликовая \\
\end{tabular} & - & $\begin{array}{c}\text { хамеродос алтайский, } \\
\text { полынь Гмелина, } \\
\text { проломник } \\
\text { щетинколистный } \\
\end{array}$ \\
\hline 8 & $\begin{array}{c}\text { С-3 } \\
\text { средняя } \\
\text { часть } \\
\text { склона }\end{array}$ & $\begin{array}{c}Л \\
0,5-0,3 \\
\text { Л }\end{array}$ & $\begin{array}{c}\text { кизильник } \\
\text { черноплодный, } \\
\text { карагана } \\
\text { мелколистная }\end{array}$ & - & $\begin{array}{c}\text { полынь холодная, } \\
\text { овсяница ленская, } \\
\text { осока стоповидная, } \\
\text { мелколепестник } \\
\text { едкий, чабрец }\end{array}$ \\
\hline 9 & $\begin{array}{c}\text { С-3 } \\
\text { подножье } \\
\text { склона }\end{array}$ & $\begin{array}{c}0,5-0, \\
\text { л }\end{array}$ & $\begin{array}{c}\text { рододендрон } \\
\text { даурский, } \\
\text { спирея } \\
\text { средняя, } \\
\text { кизильник } \\
\text { черноплодный }\end{array}$ & $\begin{array}{c}\text { синузиально. } \\
\text { Абиетинелла } \\
\text { пихтовая, } \\
\text { ритидиум } \\
\text { морщинистый, } \\
\text { дикранум } \\
\text { многоножковый } \\
\end{array}$ & $\begin{array}{c}\text { брусника, осока } \\
\text { длиннохвостая, } \\
\text { мытник } \\
\text { перевернутый }\end{array}$ \\
\hline 10 & $\begin{array}{c}\text { С-3 } \\
\text { средняя } \\
\text { часть } \\
\text { склона }\end{array}$ & $\begin{array}{c}9 Л+1 \mathrm{C} \\
0,7-0,8 \\
\text { л + ед. к }\end{array}$ & $\begin{array}{c}\text { рододендрон } \\
\text { даурский, } \\
\text { спирея средняя }\end{array}$ & $\begin{array}{c}50 \% . \\
\text { Абиетинелла } \\
\text { пихтовая, } \\
\text { ритидиум } \\
\text { морщинистый, } \\
\text { дикранум } \\
\text { многоножковый }\end{array}$ & $\begin{array}{c}\text { осока длиннохвостая, } \\
\text { прострел раскрытый, } \\
\text { подмарейник } \\
\text { северный }\end{array}$ \\
\hline 11 & \begin{tabular}{|c|} 
С-3 \\
приводо- \\
раздельный \\
склон, \\
вершина \\
\end{tabular} & $\begin{array}{c}\text { Л } \\
0,3-0,2 \\
\pi\end{array}$ & $\begin{array}{c}\text { кизильник } \\
\text { черноплодный, } \\
\text { карагана } \\
\text { карликовая }\end{array}$ & - & $\begin{array}{c}\text { лапчатка } \\
\text { пижмалистная, } \\
\text { лапчатка рассеченная, } \\
\text { овсяница ленская, } \\
\text { полынь Гмелина } \\
\end{array}$ \\
\hline 12 & $\begin{array}{c}\text { Ю-В } \\
\text { средняя } \\
\text { часть } \\
\text { склона }\end{array}$ & $\begin{array}{c}\text { Л } \\
0,3-0,2 \\
\pi\end{array}$ & $\begin{array}{c}\text { карагана } \\
\text { мелколистная, } \\
\text { кизильник } \\
\text { черноплодный } \\
\text { (ед.) }\end{array}$ & $\begin{array}{c}\text { синузиально. } \\
\text { Ритидиум } \\
\text { морщинистый, } \\
\text { дикранум } \\
\text { многоножковый, } \\
\text { абиетинелла } \\
\text { пихтовая } \\
\end{array}$ & $\begin{array}{l}\text { осока стоповидная, } \\
\text { полынь гмелина, } \\
\text { мятлик кистевидный }\end{array}$ \\
\hline 13 & $\begin{array}{c}\text { Ю-В } \\
\text { днище, } \\
\text { подножье }\end{array}$ & $\begin{array}{c}- \\
\text { единично } \\
\text { л }\end{array}$ & $\begin{array}{c}\text { карагана } \\
\text { карликовая }\end{array}$ & - & $\begin{array}{c}\text { подмаренник } \\
\text { настоящий, } \\
\text { колокольчик } \\
\text { сборный, лапчатка } \\
\text { пижмалистная, } \\
\text { зопник клубненосный }\end{array}$ \\
\hline 14 & $\begin{array}{c}\text { С-3 } \\
\text { склон, } \\
\text { вершина }\end{array}$ & $\begin{array}{c}10 \Omega \\
0,7-0,6 \\
\pi\end{array}$ & $\begin{array}{c}\text { спирея } \\
\text { средняя, } \\
\text { карагана } \\
\text { мелколистная } \\
\text { (ед.) }\end{array}$ & $\begin{array}{c}\text { синузиально. } \\
\text { Птилиум } \\
\text { гребенчатый, } \\
\text { гилокониум } \\
\text { блестящий, } \\
\text { ритидиум } \\
\text { морщинистый, } \\
\text { абиетинелла } \\
\text { пихтовая }\end{array}$ & $\begin{array}{c}\text { осока длиннохвостая, } \\
\text { астрагал } \\
\text { разноцветный }\end{array}$ \\
\hline
\end{tabular}




\begin{tabular}{|c|c|c|c|c|c|}
\hline \begin{tabular}{|l|} 
№ \\
\end{tabular} & \begin{tabular}{|c|} 
Элемент \\
рельефа, \\
морфо- \\
скульптура
\end{tabular} & $\begin{array}{c}\text { Древесный } \\
\text { ярус (состав, } \\
\text { сомкнутость, } \\
\text { подрост) }\end{array}$ & \begin{tabular}{|c|} 
Кустарниковый \\
ярус \\
(видовой \\
состав) \\
\end{tabular} & $\begin{array}{c}\text { Моховой покров } \\
\text { (проективное } \\
\text { покрытие, } \\
\text { видовой состав) }\end{array}$ & $\begin{array}{c}\text { Травянисто- } \\
\text { кустарничковый ярус } \\
\text { (виды доминанты) }\end{array}$ \\
\hline 15 & $\begin{array}{l}\text { Ю-В } \\
\text { склон }\end{array}$ & $\begin{array}{c}\text { Л } \\
0,3-0,2 \\
\pi\end{array}$ & - & - & $\begin{array}{c}\text { овсяница ленская, } \\
\text { полынь Гмелина, } \\
\text { чабрец } \\
\end{array}$ \\
\hline \begin{tabular}{|l|}
16 \\
\end{tabular} & $\begin{array}{c}\text { С-3 } \\
\text { подножье } \\
\text { склона }\end{array}$ & $\begin{array}{c}\text { - } \\
\text { единично } \\
\text { л }\end{array}$ & $\begin{array}{c}\text { карагана } \\
\text { карликовая }\end{array}$ & - & $\begin{array}{c}\text { подмаренник } \\
\text { настоящий, лапчатка } \\
\text { пижмалистная, } \\
\text { мятлик кистевидный, } \\
\text { зопник клубненосный }\end{array}$ \\
\hline 17 & $\begin{array}{c}\text { С-3 } \\
\text { средняя } \\
\text { часть } \\
\text { склона }\end{array}$ & $\begin{array}{c}Л+(C) \\
0,3-0,2 \\
\pi\end{array}$ & - & $\begin{array}{c}\text { синузиально. } \\
\text { Ритидиум } \\
\text { морщинистый, } \\
\text { дикранум } \\
\text { многоножковый }\end{array}$ & $\begin{array}{c}\text { проломник } \\
\text { щетинколистный, } \\
\text { житняк гребенчатый, } \\
\text { полынь холодная, } \\
\text { мелколепестник } \\
\text { едкий }\end{array}$ \\
\hline 18 & $\begin{array}{c}\text { С-3 } \\
\text { приводо- } \\
\text { раздельный } \\
\text { склон, } \\
\text { вершина }\end{array}$ & $\begin{array}{c}9 \text { 9Л+1C+ } \\
(\text { Б,О) } \\
0,6-0,5 \\
\text { л }\end{array}$ & $\begin{array}{c}\text { рододендрон } \\
\text { даурский, } \\
\text { спирея средняя }\end{array}$ & $\begin{array}{c}\text { 60-80\%. } \\
\text { Ритидиадельфус } \\
\text { трехрядный, } \\
\text { политрихум } \\
\text { обыкновенный, } \\
\text { гилокониум } \\
\text { блестящий, } \\
\text { абиетинелла } \\
\text { пихтовая }\end{array}$ & $\begin{array}{c}\text { брусника, осока } \\
\text { длиннохвостая, } \\
\text { мятлик лесной, } \\
\text { подмаренник } \\
\text { северный, прострел } \\
\text { раскрытый, } \\
\text { купальница азиатская }\end{array}$ \\
\hline \begin{tabular}{|l|}
19 \\
\end{tabular} & $\begin{array}{c}\text { Ю-В } \\
\text { приводо- } \\
\text { раздельный } \\
\text { склон }\end{array}$ & $\begin{array}{c}\text { C } \\
\text { куртины } \\
\text { с }\end{array}$ & \begin{tabular}{|c|} 
карагана \\
мелколистная, \\
кизильник \\
черноплодный
\end{tabular} & $\begin{array}{c}\text { синузиально. } \\
\text { Ритидиум } \\
\text { морщинистый, } \\
\text { абиетинелла } \\
\text { пихтовая, } \\
\text { дикранум } \\
\text { многоножковый }\end{array}$ & $\begin{array}{c}\text { овсяница ленская, } \\
\text { мятлик кистевидный, } \\
\text { астрагал } \\
\text { разноцветный, осока } \\
\text { стоповидная }\end{array}$ \\
\hline
\end{tabular}

Именно на Приольхонском плато и побережье оз. Байкал особенно ярко выражена экспозиционная контрастность ландшафтов. На южных склонах, днищах долин и в котловинах преобладают степные и сухо-степные крио-ксерофильные фации мелкозлакового, мелкодерновинно-злакового и низкоразнотравного типа с доминированием среди растений ксерофитов в сочетании с лиственничными рединами. На северных склонах формируются остепненные лиственничники (часто редколесные) с сосной в основном с мелкодерновинно-злаковым и низкотравным травянистым покровом в сочетании с разнотравными и злаковонизкотравными фациями.

Леса подтаежного типа развиты на полигоне фрагментарно и только на северных и северо-восточных склонах. Они представлены в основном редкостойными спирейно-разнотравными остепненными лиственничниками с участием кустарников и синузиями мхов, реже зеленомошно-осоковыми лиственничниками со слаборазвитым подростом и подлеском из рододендрона даурского. Кустарниковая 
и луговая растительность распространена узкими полосами вдоль русел рек и по днищам широких распадков. Склоны вдоль береговой линии Байкала заняты разреженной степной растительностью с отдельно стоящими лиственницами и соснами.

\section{Заключение}

Выявленное распределение фаций, урочищ и местностей на полигоне отражает основные закономерности ландшафтной структуры Приольхонья. Эти закономерности обусловлены: а) микро- и мезоклиматическими различиями инсоляции и увлажнения вследствие экспозиционного положения и удаленности от оз. Байкал; б) морфологией поверхности, особенностями проявления ведущих геоморфологических процессов, различиями реакции горных пород на их воздействие; в) литологической и петрографической неоднородностью подстилающих горных пород.

Ландшафтная структура Приольхонья сильно зависит от пестроты почвенного покрова. Различия в мощности, хрящеватости и щебнистости распространенных в районе исследования почв, отражающие особенности взаимодействия экзогенных процессов и горных пород, влекут за собой преобразования в их тепловом и водном режимах, приводят к изменению почвообразовательных процессов, смене фитоценоза.

В плане исследования структуры растительного покрова важным представляется следующий вывод. Внедрение элементов мезофитного разнотравья в ксероморфные степные фации южных склонов и суходолов по пониженным формам рельефа и, наоборот, ксерофильных видов растений на северные склоны, в т. ч. и под полог лиственничников по литоморфным участкам, создает очень сложную мозаику пространственной структуры ландшафтов Приольхонья. Эта мозаика редко где на байкальском побережье проявляется в такой контрастности и полноте.

В целом следует сказать, что все компоненты ландшафта - горные породы, рельеф, геоморфологические процессы, почвенный и растительный покров активно участвуют в формировании его структуры непосредственно через распределение и перераспределение потоков вещества и энергии. Это участие взаимосвязанное и взаимоопосредованное, приводит к созданию специфического ландшафтного облика Приольхонья, обеспечивает высокое ландшафтное и биологическое разнообразие территории.

\section{Литература}

1. Баженова О. И., Мартьянова Г. Н. Формирование экстремальных морфоклиматических ситуаций на юге Сибири // География и природные ресурсы. 2004. № 4. С. 87-94.

2. Данько Л. В. Эволюция почв экотона тайги и степи Прибайкалья // География и природные ресурсы, 2009. № 4. С. 17-25.

3. Касьянова Л. Н. Экология растений степей Приольхонья. Новосибирск: Наука, 1993. $159 \mathrm{c}$.

4. Классификация и диагностика почв России / Л. Л. Шишов, В. Д. Тонконогов, И. И. Лебедева, М. И. Герасимова. Смоленск: Ойкумена, 2004. 342 с.

5. Кузьмин В.А. Почвы Центральной зоны Байкальской природной территории. Иркутск: Изд-во ИГ СО РАН, 2002. 166 с.

6. Кузьмин С.Б., Данько Л.В. Палеоэкологические модели этноприродных взаимодействий. Новосибирск: ГЕО, 2011. 187 с. 
7. Кузьмин С.Б., Шаманова С.И. Усовершенствование метода выделения ярусов рельефа на основе его цифровых моделей и характера древесной растительности на примере Западного Прибайкалья // Известия РАН. Серия географическая. 2012. № 4. С. 83-92.

8. Кузьмин С.Б., Шаманова С.И., Казановский С.Г. Определение высотной поясности ландшафтов на базе цифровых моделей рельефа и характера дендрофлоры // География и природные ресурсы, 2012. № 4. С. 137-149.

9. Кузьмин С. Б., Белозерцева И. А., Шаманова С. И. Палеогеографические события Приольхонья в голоцене // Международный журнал прикладных и фундаментальные исследований. 2014. Ч. 3, № 10. С. 54-68.

10. Кузьмин С. Б., Хлыстов О. М., Мехоношин П. А., Абалаков А. Д., Шаманова С. И. Изучение рыхлых отложений побережья и акватории Малого моря на Байкале для восстановления природно-геодинамических обстановок в позднеледниковье и голоцене // Географический вестник. 2016. № 1. С. 23-36.

11. Ландшафты юга Восточной Сибири. Карта. М 1:1500000 / под ред. В. С. Михеева и В. А. Ряшина М.: ГУГК, 1977.

12. Михеев В. С. Ландшафтный синтез географических знаний. Новосибирск: Наука, 2001. $216 \mathrm{c}$.

13. Моложников В. Н. Растительные сообщества Прибайкалья. Новосибирск: Наука, 1986. $270 \mathrm{c}$.

14. Пешкова Г. А. Флорогенетический анализ степной флоры гор Южной Сибири. Новосибирск: Наука, 2001. 192 с.

15. Раменский Л. Г. Введение в комплексное почвенно-геоботаническое исследование земель. М.: Сельхозгиз, 1938. 620 с.

16. Сизых А. П. Картографирование растительных сообществ контакта сред (на примере западного побережья оз. Байкал). Иркутск: Изд-во Ин-та географии СО РАН, 2015. $129 \mathrm{c}$.

17. Снытко В. А., Данько Л. В., Кузьмин С. Б., Сизых А. П. Разнообразие геосистем контакта тайги и степи западного побережья Байкала // География и природные ресурсы, 2001. № 2. С. 61-68.

18. Снытко В. А., Данько Л. В. Почвенно-геохимическая специфика экотонов тайги и степи Приольхонья // География и природные ресурсы, 2004. № 1. С. 59-65.

19. Солнцев Н. А. Учение о ландшафте. Избранные труды. М.: Изд-во МГУ, 2001. 384 с.

20. Фридланд В. М. Структура почвенного покрова. М.: Мысль, 1972. 422 с.

21. Цыбжитов Ц. Х., Цыбикдоржиев Ц. Ц., Цыбжитов А. Ц. Почвы бассейна озера Байкал. Генезис, география и классификация каштановых почв. Новосибирск: Наука, 1999. $128 \mathrm{c}$.

22. Экологически ориентированное планирование землепользования в Байкальском регионе. Ольховский район / под ред. Ю. М. Семенова и А. Н. Антипова. Иркутск: Изд-во ИГ CO PAH, 2004. 147 c.

\section{LANDSCAPE STRUCTURE OF PREOLKHON REGION}

\section{S. B. Kuzmin, S. I. Shamanova}

Sergey B. Kuzmin

Dr. Sci. (Geogr.), Leading Researcher,

Sochava Institute of Geography SB RAS,

1 Ulanbatorskaya St., Irkutsk 664033, Russia

kuzmin@irigs.irk.ru 
Svetlana I. Shamanova

Cand. Sci. (Biol.), Researcher,

Siberian Institute of Plant Physiology and Biochemistry SB RAS

136 Lermontova St., Irkutsk 664033, Russia

shamanova2009@yandex.ru

Abstract. The article studies the landscape structure of the transect polygon in Preolkhon Region, Western Baikal coast. As a result of the research, we have established that the nature of geomorphological processes and the corresponding complex of loose deposits is closely related to differences in solar, circulation and gravitational exposure of slopes. Slope exposure and surface morphology affect the soil cover structure and soil characteristics. Analysis of the distribution of soils in landscapes revealed independent slope exposure series of soils northern and southern. The plant communities of the southeastern and northwestern slopes differ in their species composition. The change in geomorphological conditions within the slopes of a certain exposure determines a number of plant communities successively replacing each other as the lithomorphism and degree of substrate moisture change. Within the boundaries of the transect polygon, we have been identified 19 facies, the spatial distribution of which reflects the main patterns of differentiation of the Preolkhon Region landscapes, caused by micro- and mezoclimatic differences in exposure position, distance from Lake Baikal, surface morphology; the peculiarities of the manifestation of the leading geomorphological processes and the differences in the reaction of rocks to their impact; lithological heterogeneity of the underlying surface.

Keywords: spatial structure of landscapes; geomorphological conditions; soils; structure of vegetation; Western Baikal Region.

Статья поступила в редакцию 17.11.20; одобрена после редактирования 16.12.20; принята к публикации 18.12 .20 . 